\title{
Comparison of Mini-Micro LNG and CNG for commercialization of small volumes of associated gas
}

Prepared by TRACTEBEL ENGINEERING S.A.

October 2015 


\section{TABLE OF CONTENTS}

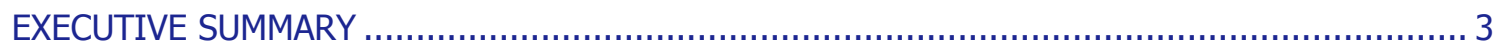

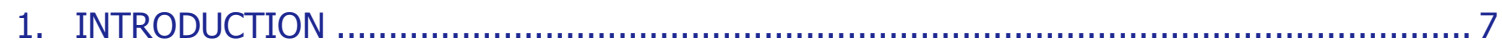

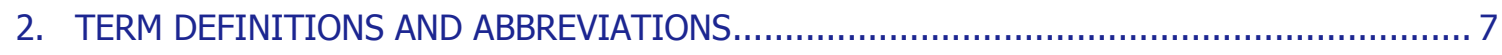

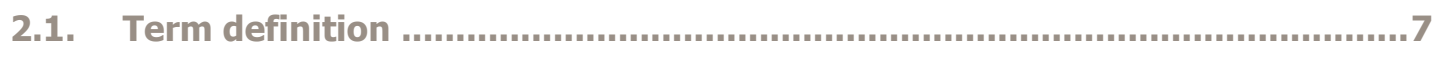

2.2. Abbreviations ......................................................................................

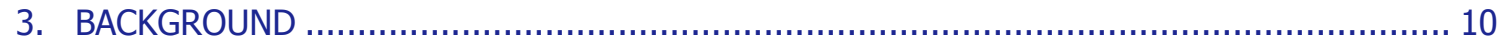

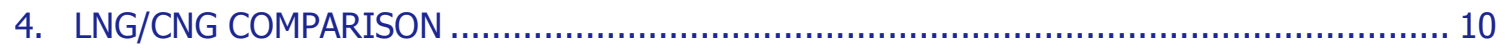

4.1. General I.............................................................10

4.2. Chain operation ........................................................................11

5. TECHNICAL COMPARISON OF THE LNG/CNG CHAINS …........................................... 12

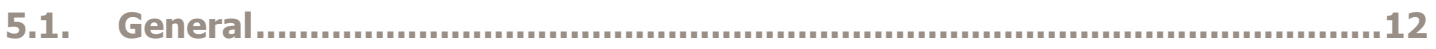

5.2. Feed gas treatment...

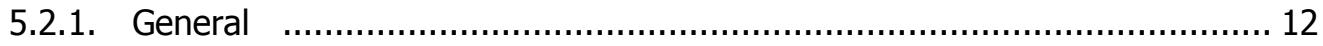

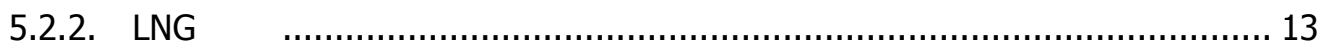

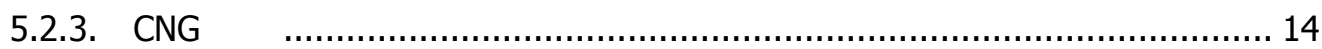

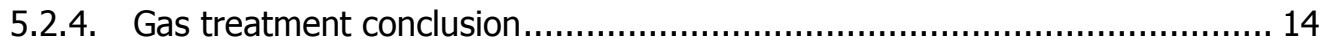

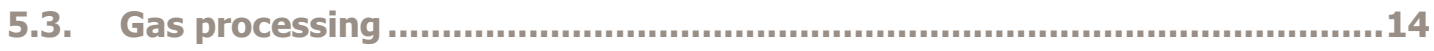

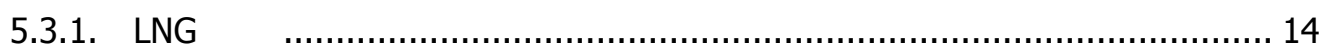

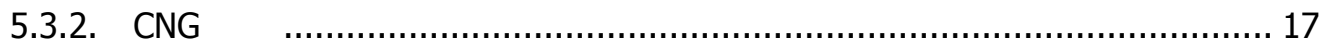

5.4. Loading and unloading ............................................. 20

5.4.1. LNG

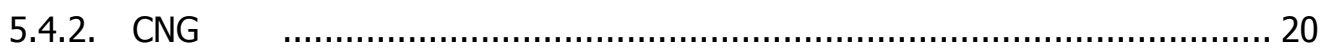

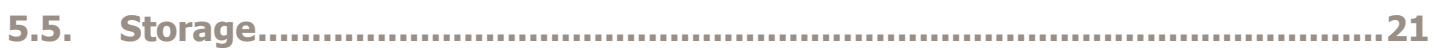

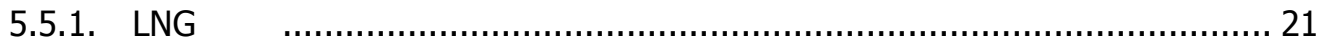

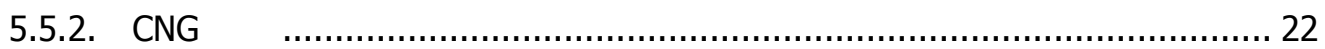

5.6. Marine transportation ......

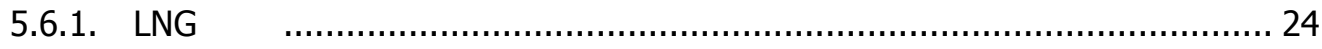

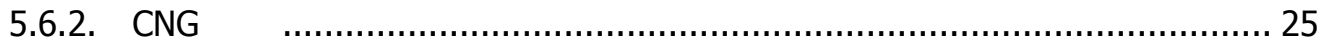

5.7. River transportation .................................................. 27

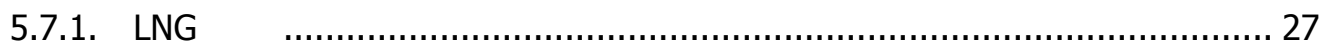

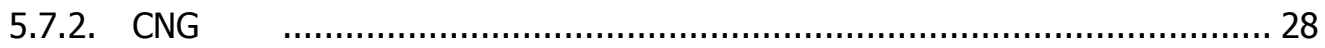


5.8. Truck transportation $\ldots \ldots \ldots \ldots \ldots \ldots \ldots$

5.8.1. LNG

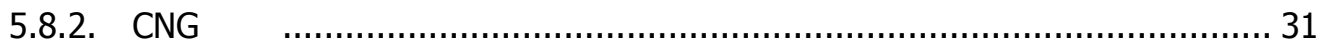

5.9. Utilisation of LNG and CNG

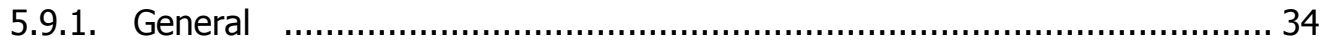

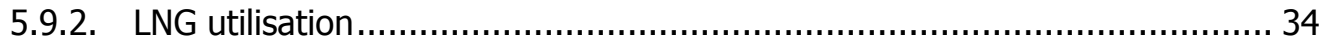

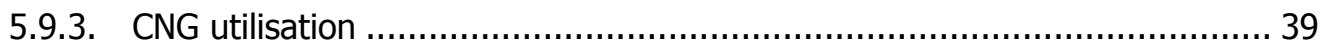

5.10. Safety 39

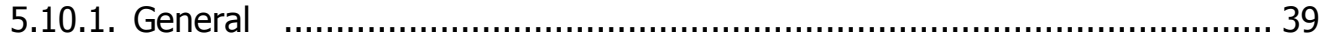

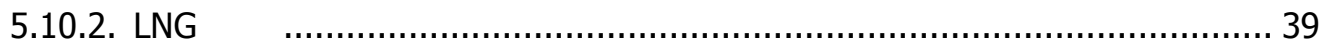

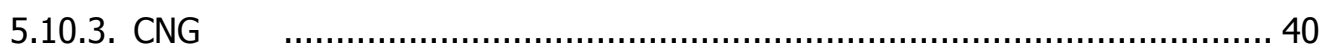

5.11. Technical comparison of the elements in LNG \& CNG chains ...................40

5.12. Suitability for associated gas recovery ...................................................41

6. COSTS

6.1. General...................................................................................................42

6.2. Gas treatment costs ........................................................................42

6.3. LNG chain costs....................................................................................43

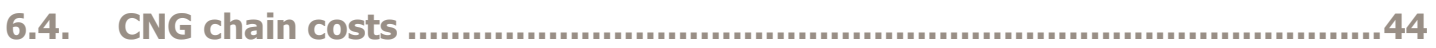

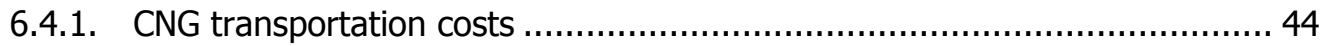

6.4.2. CNG price at delivery point................................................................ 48

6.5. Cost examples

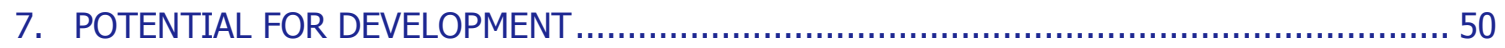

7.1. General..............................................................................................50

7.2. Experience

7.2.1. USA

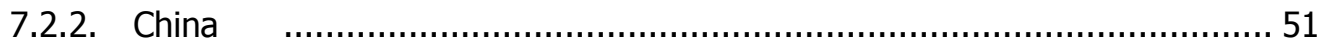

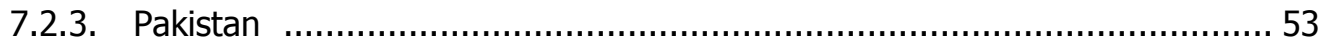

7.2.4. Other experiences .......................................................................... 53

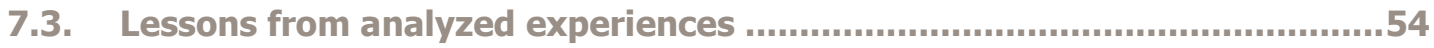

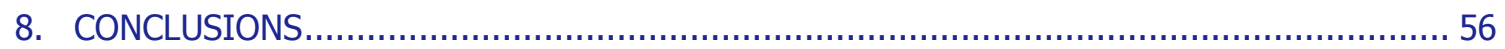

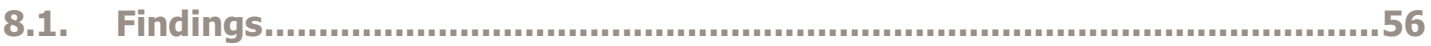

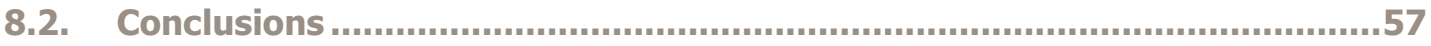




\section{EXECUTIVE SUMMARY}

The Global Gas Flaring Reduction Partnership (GGFR) provides its members with overviews of the potential solutions to recover and monetize the flared and/or associated gas. This study analyses two options that could be used for this monetization of small volumes (1 -15 MMscf/d): the LNG and CNG chain concepts.

Technologies are available for both concepts, with different maturity level from the gained experiences and for different transportation conditions (quantities, distances). The available technologies allow a choice of implementation options to suit the volume of gas to be transported and the distance from field to consumer.

The cost of the chain depends upon the parameters governing the gas recovery, its transportation and its delivery. Among these parameters the most important are the gas volume and the transportation distance.

As examples, two gas volumes ( $3 \& 10 \mathrm{MMscf} / \mathrm{d}$ ) and two ranges of distance to markets/consumers, have been evaluated for a projects with 15 year durations: 


\begin{tabular}{|c|c|c|c|c|c|}
\hline \multicolumn{6}{|c|}{ Long distance } \\
\hline \multirow{8}{*}{$\begin{array}{l}\frac{0}{0} \\
\frac{2}{4} \\
\frac{5}{4} \\
\frac{4}{5}\end{array}$} & \multicolumn{5}{|c|}{ All cost in USD $D_{(2025)} /$ MMBTU } \\
\hline & & \multicolumn{2}{|c|}{ Marlne - 3MMSCFD / 550-800 MN } & \multicolumn{2}{|c|}{ Marlne - 10MMSCFD / 550-800 MN } \\
\hline & items & LNG & CNG & LNG & ONG \\
\hline & Gos Treatment & 0.42 & 0.42 & 0.21 & 0.21 \\
\hline & Processing (liquefoction/Compression) & 4.71 & 0.73 & 3.71 & 0.70 \\
\hline & $\begin{array}{cc}\text { Trans portation } \\
\end{array}$ & 3.36 & 6.43 & 2.86 & 5.22 \\
\hline & Delivery & 1.56 & 0.5 & 1.06 & 0.5 \\
\hline & Total & 10.05 & 8.08 & 7.84 & 6.63 \\
\hline \multirow{8}{*}{$\begin{array}{l}\frac{0}{6} \\
\frac{8}{5} \\
\frac{8}{b}\end{array}$} & \multicolumn{5}{|c|}{ All cost in USD ${ }_{[2013 / M M B T U}$} \\
\hline & & \multicolumn{2}{|c|}{ Truck-3MM5CFD / 750-1000 Ml } & \multicolumn{2}{|c|}{ Truck-10MMSCFD / 750-1000 Ml } \\
\hline & Hems & LNG & CNG & LNG & CNG \\
\hline & Gos Treatment & 0.42 & 0.42 & 0.21 & 0.21 \\
\hline & Processing (liquefoction/Com pression) & 4.71 & 0.73 & 3.71 & 0.70 \\
\hline & \begin{tabular}{ll|} 
Trons portotion \\
\end{tabular} & 4.93 & 8.81 & 4.68 & 8.79 \\
\hline & Delivery & 1.56 & 0.50 & 1.06 & 0.50 \\
\hline & Total & 11.62 & 10.46 & 9.66 & 10.20 \\
\hline \multicolumn{6}{|c|}{ Short Distance } \\
\hline \multirow{8}{*}{$\begin{array}{l}\frac{0}{0} \\
\frac{8}{\sqrt{3}} \\
\frac{4}{0}\end{array}$} & \multicolumn{5}{|c|}{ All cost in USD $\mathrm{D}_{[2015} / \mathrm{MMBTU}$} \\
\hline & & \multicolumn{2}{|c|}{ Marlne-3MMSCFD / $55-150 \mathrm{MN}$} & \multicolumn{2}{|c|}{ Marlne-10MMSCFD / 55-150 MN } \\
\hline & Items & ING & CNG & LNG & ONG \\
\hline & Gos Treatment & 0.42 & 0.42 & 0.21 & 0.21 \\
\hline & Processing (liquefoction/Compression) & 4.71 & 0.73 & 3.71 & 0.70 \\
\hline & $\begin{array}{cc}\text { Trans portation } \\
\end{array}$ & 2.36 & 3.00 & 1.86 & 2.40 \\
\hline & Delivery & 1.56 & 0.5 & 1.06 & 0.5 \\
\hline & Total & 9.05 & 4.65 & 6.84 & 3.81 \\
\hline \multirow{8}{*}{$\frac{0}{5}$} & \multicolumn{5}{|c|}{ All cost in $U_{S D_{(202 s} / M M B T U}$} \\
\hline & & \multicolumn{2}{|c|}{ Truck-3MMSCFD / 0-250 Ml } & \multicolumn{2}{|c|}{ Truck-10MM5CFD / 0-250 Ml } \\
\hline & thems & $\underline{\underline{L N G}}$ & CNG & LNG & CNG \\
\hline & Gos Treatment & 0.42 & 0.42 & 0.21 & 0.21 \\
\hline & Processing (liquefoction/Com pression) & 4.71 & 0.73 & 3.71 & 0.70 \\
\hline & $\begin{array}{cc}\text { Trans portation } \\
\end{array}$ & 1.43 & 2.20 & 1.18 & 2.20 \\
\hline & Delivery & 1.56 & 0.50 & 1.06 & 0.50 \\
\hline & Total & 8.12 & 3.85 & 6.16 & 3.61 \\
\hline
\end{tabular}


The above data can be summarized as follows:
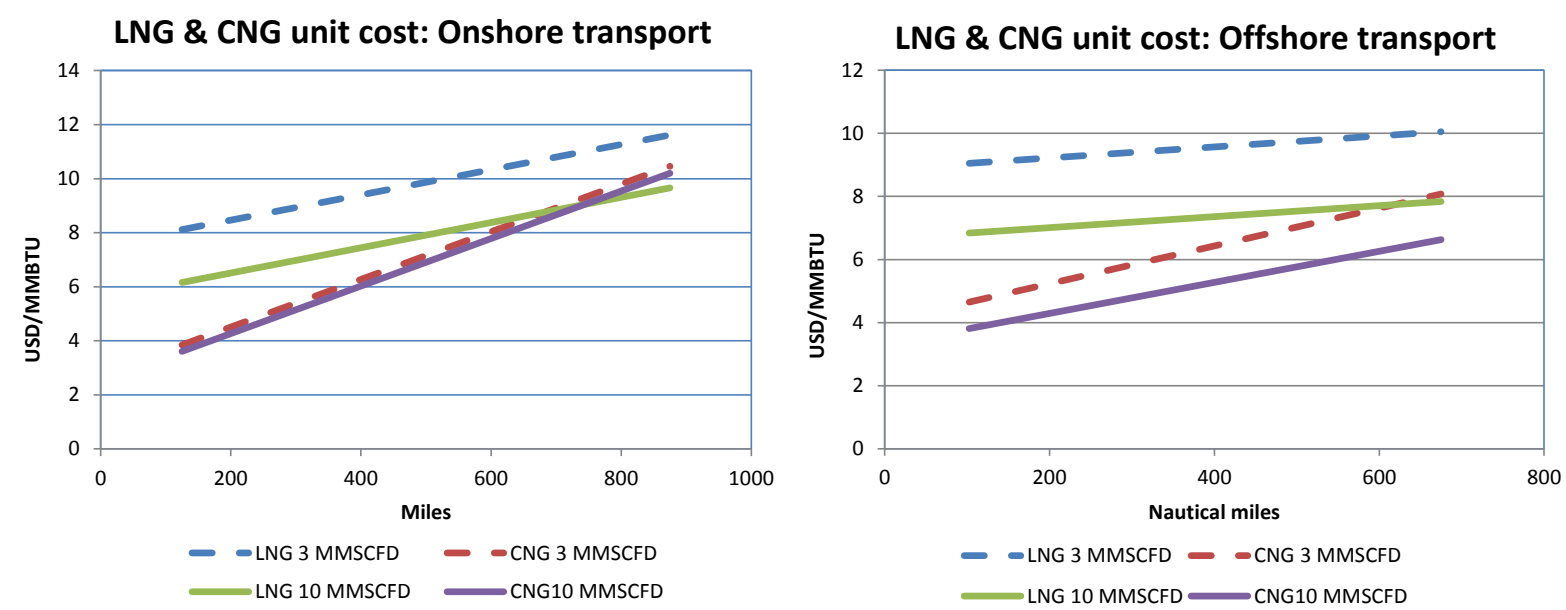

It should be noted that $\mathrm{CNG}$ is considered to be less suitable for larger gas volumes and longer distances due to the large CNG transport requirements (ships, barges or trucks) resulting from its lower volumetric efficiency; even with the best CNG container option, CNG requires at least twice the LNG chain transportation fleet for the same gas volume. The large scale of the CNG loading facilities also required for large gas volumes reinforces this conclusion.

From the comparison:

1. Gas treatment is similar for both options, although CNG may need slightly less treatment when the gas is relatively clean

2. LNG liquefaction is more complex than CNG compression, and requires more capital investment

3. CNG is perceived as being of a higher safety risk, due to the high operating pressure, in the range of $150-250$ barg

4. The volumetric efficiency (reduction of the gas volume relative to atmospheric conditions) is 150 to $300: 1$ for CNG, compared to LNG at approximately 600:1

5. The higher capital costs of an LNG chain give CNG a cost advantage for smaller volumes and shorter distances. At higher volumes and longer distances, higher CNG chain operating costs reverse this advantage.

6. As noted above, CNG is considered to be less suitable for larger gas volumes and longer distances due to the large CNG transportation requirement (ships, barges or trucks). The large scale of the $\mathrm{CNG}$ loading facilities also required for large gas volumes reinforces this conclusion.

7. It is recommended that CNG should be limited to $5 \mathrm{MMscf} / \mathrm{d}$ and to $800 \mathrm{~km}$ in the case of road transportation for cost and operational complexity reasons, whilst CNG marine transportation is typically for large volumes and should be limited to less than 2,000 Nautical Miles 
Experience in USA, China and Pakistan shows that the gas transportation solutions have been more developed when there is a gap in the traditional gas infrastructure (pipeline). The solutions are more oriented to LNG chains for higher quantities and longer distances whilst they are more developed for CNG as fuel for vehicles. It is also apparent that attractive gas prices are often the result of strategic public policies, with laws promoting reduction in emissions or incentives via differential taxation.

Finally the implementation of the solutions to recover and monetize the flared and/or associated gas needs to gather the conditions that make the project viable:

- The market demands

- The gas price attractiveness

- The existence of transportation infrastructure (road, river, etc.) to ensure a safe and reliable gas delivery.

The market currently offers some attractive niche opportunities:

- The gas to power, for electricity generation up to $50 \mathrm{MW}$

- $\mathrm{CNG}$ as fuel for vehicles

- LNG as fuel for large vehicles (trucks, locomotives, buses, etc.)

- LNG bunkering for ships, barges, ferries, etc.

The technologies and demand are there. The opportunities must be created. 


\section{INTRODUCTION}

The purpose of this report is to compare the LNG and CNG chain concepts that could be used to monetise small volumes (1-15MMscf/d) of associated gas and avoid or reduce the current gas flaring.

Both LNG and CNG concepts have been developed for over 50 years in similar though not exactly the same ways, and have gained some maturity as a result of the gas market expansion.

The CNG and LNG reports ${ }^{1}$ analysed the available technologies and the development of the respective chains in specific countries for a better understanding of the mechanism of their evolution and for possible application in other emerging countries.

This report will compare both CNG and LNG chain concepts for small volumes monetisation and will identify the drivers that could increase their implementation to reduce gas flaring and its consequential emissions.

\section{TERM DEFINITIONS AND ABBREVIATIONS}

\subsection{Term definition}

- Supplier: a supplier of equipment or system, but also a developer of specific technologies

\subsection{Abbreviations}

The following abbreviations are used in this report:
AAV
Ambient Air Vaporizer
$\mathrm{Bcf}$
Billion cubic feet
$\mathrm{Bcm}$
Billion cubic meters
BTU
British Thermal Unit
CAPEX
CApital EXPenditure
CMS
CNG Mother Station

\footnotetext{
${ }^{1}$ Respectively:

- $\quad$ LNG report: LNG report: STUDY IN MINI/MICRO LNG AND CNG FOR COMMERCIALIZATION OF SMALL VOLUMES OF ASSOCIATED GAS MINI/MICRO LNG REPORT ref: WB_GGFR_4NT_0349855_000_00

- $\quad$ CNG report: STUDY IN MINI/MICRO LNG AND CNG FOR COMMERCIALIZATION OF SMALL VOLUMES OF ASSOCIATED GAS CNG REPORT ref: WB_GGFR_4NT_0353148_000_00
} 


\begin{tabular}{ll} 
CNG & Compressed Natural Gas \\
CNOOC & China National Offshore Oil Corporation \\
CNPC & China National Petroleum Corporation \\
CO2 & Carbon Dioxide \\
CTC & Cargo Tank Cylinder \\
DNV & Det Norske Veritas \\
FDI & Foreign Direct Investment \\
FSRU & Floating Regasification and Storage Unit \\
GDP & Gross Domestic Product \\
GGFR & Global Gas Flaring Reduction \\
GHG & Greenhouse Gas \\
GHV & Gross Heating Value \\
GMP & Gas Master Plan (Nigeria) \\
GNSL & International Finance Corporation \\
GPD & Gas Network Services Limited \\
GTL & Gallons Per Day \\
GTU & Gas to liquid \\
GW & Gas Treatment Unit \\
HDP & High Watt \\
\hline IFV & Intuid Vaporizer \\
\hline
\end{tabular}


Liquefied Natural Gas

Liquid Petroleum Gas

$\mathrm{Mcm}$

Million Cubic Meters

MEGC

Multi-Element Gas Container

MIGA

Multilateral Investment Guarantee Agency

Mi

MJ

MMBTU

MMscf/d

$\mathrm{MN}$

MR

MTPA

$\mathrm{N} 2$

$\mathrm{NaMi}$

NBET

NFPA

ng

NGL

NGO

NGV

NGVA

NIRP

OPEX

ORV

PIB

Miles

Mega Joules

Millions of BTU

Million Standard Cubic Feet per Day

Nautical Mile

Mixed Refrigerant

Million Tonnes Per Annum

Nitrogen

Nautical Miles

Nigerian Bulk Electricity Trading PLC

National Fire Protection Association

Nano gram

Natural Gas Liquids

Non-Governmental Organization

Natural Gas Vehicle

Natural and Bio Gas Vehicle

Nigeria Industrial Revolution Plan

OPerating EXpenses

Open Rack Vaporizer

Petroleum Industry Bill 


$\begin{array}{ll}\text { PLN } & \text { Perusahaan Listrik Negara } \\ \text { ppm } & \text { Parts Per Million } \\ \text { SBC } & \text { Schlumberger Business Consulting } \\ \text { SCV } & \text { Submerged Combustion Vaporizer } \\ \text { SMR } & \text { Single Mixed Refrigerant } \\ \text { SPDC } & \text { Shell Petroleum Development Company of } \\ & \text { Nigeria Limited } \\ \text { STV } & \text { Shell and Tube Vaporizer } \\ \text { t } & \text { Tons } \\ \text { tpd } & \text { Tons per day } \\ \text { USD } & \text { United States Dollar } \\ \text { VOTRANS } & \text { Volume Optimized Transport and Storage } \\ & \text { System }\end{array}$

\section{BACKGROUND}

The Global Gas Flaring Reduction Partnership (GGFR) is a public-private partnership, hosted by the World Bank, which brings together a wide range of countries and companies to work together to reduce gas flaring and utilize gas, currently flared, in economically beneficial ways.

The GGFR Partnership was initiated in 2002 and has been active since in providing advice and guidance to GGFR Partners on a wide variety of flaring related issues including regulation, measurement, reporting, and utilisation technologies.

The GGFR intends to provide its partners with an overview of these potential solutions to monetise the associated gas in order to decrease the global associated gas flaring.

\section{LNG/CNG COMPARISON}

\subsection{General}

The comparison will address the respective chain concepts, the available technologies and their potential for development. 
This comparison is based upon the reports that have been produced as part of this flared gas recovery and monetisation study, respectively:

- Mini/Micro LNG report referenced WB_GGFR_4NT_0349855_000_00

- CNG report referenced WB_GGFR_4NT_0353148_000_00

The recovery of flared gas (or associated gas) can be based on both LNG and CNG chains and technologies.

The chains are similar, even if using different technologies, and are composed of the same functions:

- Associated gas treatment

- Gas processing (liquefaction or compression)

- LNG or CNG loading for transportation

- LNG or CNG transportation

- LNG or CNG unloading

- LNG or CNG utilisation / distribution

However the chains have their own specific requirements and the suppliers have developed the necessary technologies to undertake the above functions.

\subsection{Chailn operation}

In the chain development, the operational approaches are different for each option.

Whilst the LNG chain is based on high volume gas storage at either end with the use of large volume shuttle-type transportation in between, the CNG chain is considered as more of a continuous flow without intermediate high volume buffer gas storage.

Typically in the LNG chain, the LNG shuttles are loading and unloading their cargo at a high rate to reduce the ship demurrage costs. These (un)loading rates are significantly different from the LNG production or consumption rates. Therefore LNG buffer tanks are installed at both ends of the chain to absorb these flow differences.

The CNG industry is currently working on the basis of loading and unloading of the marine or land transportation container at respectively the CNG source and the gas consumers without buffer storage.

These different approaches have a direct impact on the operating costs, mainly for the transportation and the required transport fleet mobilisation (number of respective trucks).

With the growth of mini and micro chains, it is possible that these approaches could be revisited in both options to optimise the investment and operating costs. 


\section{TECHNICAL COMPARISON OF THE LNG/CNG CHAINS}

\subsection{General}

The following section will review the technical components and their characteristics. The technical comparison will address the available technologies for the required functions as listed in section 4 and will include a specific overview of the safety aspects.

\subsection{Feed gas treatment}

\subsubsection{General}

The gas processing in both options required prior gas treatment.

Generally the pressure in an oil reservoir decreases over time as the oil is produced. The crude oil production rate is typically kept constant during a given duration (plateau) and then gradually decreases as the reservoir pressure declines. On the surface the wellhead pressure also decreases, leading to the requirement to reduce the oil/gas pressure accordingly. As a consequence the associated gas will be produced at a flow rate, pressure and quality varying with time over the life of the oil reservoir.

As reservoirs are mostly made of water saturated rocks, the hydrocarbons produced from a well are generally water saturated. Gas produced from oil reservoirs can also contain impurities such as $\mathrm{CO} 2, \mathrm{H} 2 \mathrm{~S}$, Mercury, Nitrogen and its nature is such that heavy hydrocarbon components are typically at higher concentrations than in gas reservoirs. The composition of the gas will vary over time, as with the other parameters. The gas treatment capacity should therefore be flexible to re-adjust its performance to match the actual gas composition and impurities.

Typical compositions of associated gas are given as an example in Table 1 while each field and sometimes even each well has its own production characteristics.

\begin{tabular}{c|c|c} 
Component & Lean Gas & Rich Gas \\
\hline Methane & 92.32 & 81.62 \\
Ethane & 3.25 & 8.17 \\
\hline Propane & 1.80 & 4.49 \\
\hline i-Butane & 0.43 & 1.44 \\
\hline n-Butane & 0.62 & 1.54 \\
\hline i-Pentane & 0.00 & 0.28 \\
\hline n-Pentane & 0.00 & 0.45
\end{tabular}




\begin{tabular}{l|c|c} 
Component & Lean Gas & Rich Gas \\
\hline Hexane & 0.00 & 0.11 \\
\hline C7+ & 0.00 & 0.09 \\
Helium & 0.00 & 0.01 \\
\hline Nitrogen & 0.69 & 0.94 \\
\hline Carbon dioxide & 0.89 & 0.86 \\
\hline total & 100.00 & 100.00 \\
\hline $\begin{array}{l}\text { Molecular } \\
\text { weight }\end{array}$ & 17.78 & 20.62 \\
\hline
\end{tabular}

Table 1: Typical associated gas composition, mole \%

\subsubsection{LNG}

The gas treatment facilities must be designed to match the requirements of the liquefaction process and of the end users.

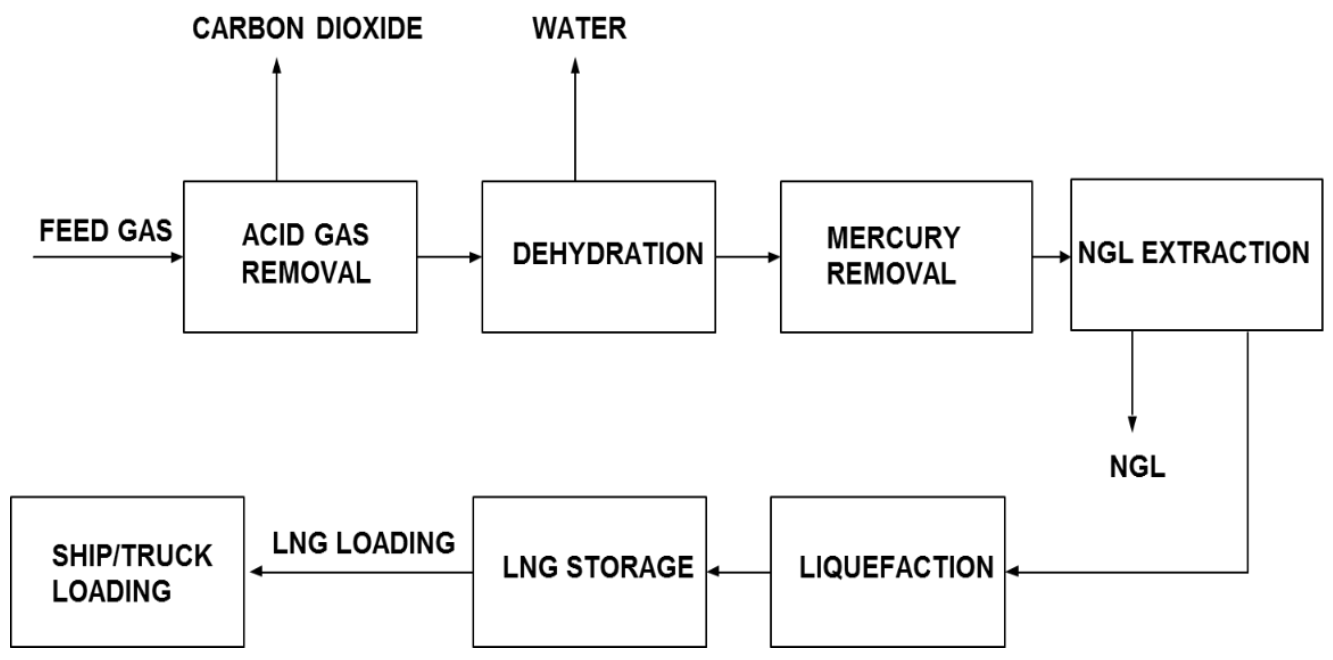

Figure 1: Gas treatment block flow diagram

The gas pre-treatment will depend on the feed gas composition and on the requirements of the liquefaction process, but basically it consists of:

- Acid gas removal unit: to remove acid gases $\left(\mathrm{CO}_{2}\right.$ and $\left.\mathrm{H}_{2} \mathrm{~S}\right)$ to prevent freezing out, blockage and corrosion in the downstream liquefaction unit.

- Dehydration: to remove water to prevent ice and hydrate formation in the liquefaction unit. 
- Mercury removal: to reduce the mercury level in the feed gas to prevent corrosion in the (aluminium) heat exchanger.

- NGL (condensate) extraction: to remove heavy hydrocarbons to prevent freezing in the cryogenic sections and/or to meet the required LNG specification (i.e. GHV or Wobbe Index).

Typically the feed gas composition after treatment should comply with following requirements (impurities are by weight):

- Water - less that $0.1 \mathrm{ppm}$.

- Sulphur - less than 3 ppm (this could be H2S or mercaptans).

- Benzene - less than 4-6 ppm (depending on ethane content in LNG)

- Toluene - less than 50-100 ppm

- Carbon Dioxide - less than 60 - 100 ppm

- Mercury - less than $0.1 \mathrm{ng} / \mathrm{Nm} 3$

\subsubsection{CNG}

In the case of CNG, specific treatment criteria are not very well defined by technology providers as they are more focused on CNG transportation options than the gas processing (the compression).

The gas conditioning that typically is required for $\mathrm{CNG}$ includes:

- Removal of heavy hydrocarbons to avoid condensation

- Removal of contaminants

- Dehydration

\subsubsection{Gas treatment conclusion}

The gas conditioning is mainly required to ensure that the quality of the associated gas is aligned to the end user gas specification rather than to suit the actual processing system. The gas conditioning for CNG is therefore similar to that required for liquefaction, though it actually requires slightly less treatment.

\subsection{Gas processing}

\subsubsection{LNG}

In the LNG chain, the gas processing consists in liquefaction and then storage at cryogenic temperatures. 
The liquefaction process is a mature technology. The mini-liquefaction is a relatively recent development, but is supported by 50 years of experience in LNG export terminals or peakshaving ${ }^{2}$ facilities.

The LNG composition will be determined by the consumers' requirements with regard to gas composition or GHV.

There are several processes available to liquefy natural gas, developed by different companies under licences. The most commonly used mini and micro liquefaction processes are based upon one of the following technologies:

The following figures illustrate the main small-scale liquefaction technology types; the figures are from Black \& Veach, but the basic processes are similar for other technology providers.

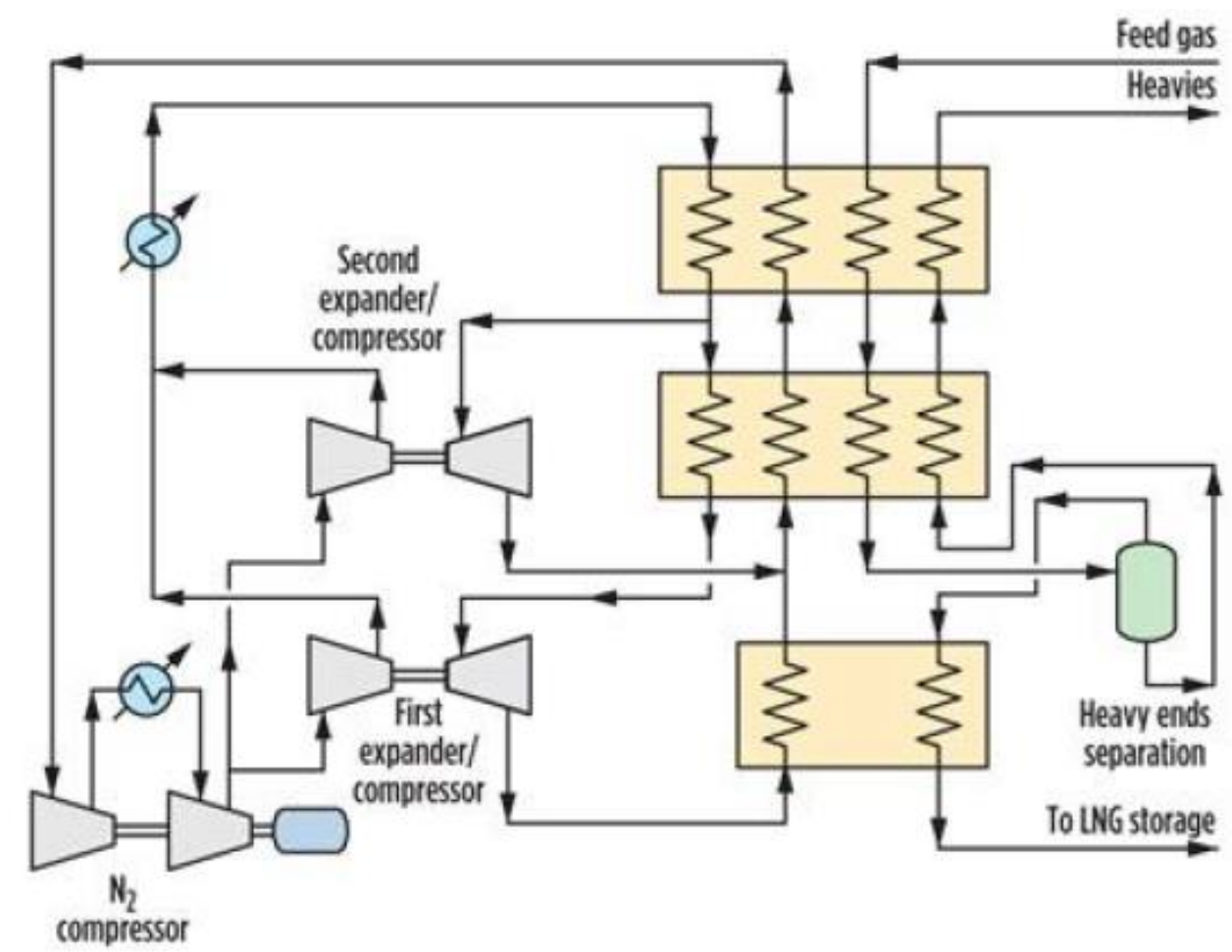

Figure 2: Nitrogen and gas expansion

\footnotetext{
${ }^{2}$ Plants that are connected to a gas network and that is used to balance the gas demands. During the period of the year when gas demand is low, natural gas is liquefied and stored. The stored LNG may then be vaporised for short periods, when gas demand is high.
} 


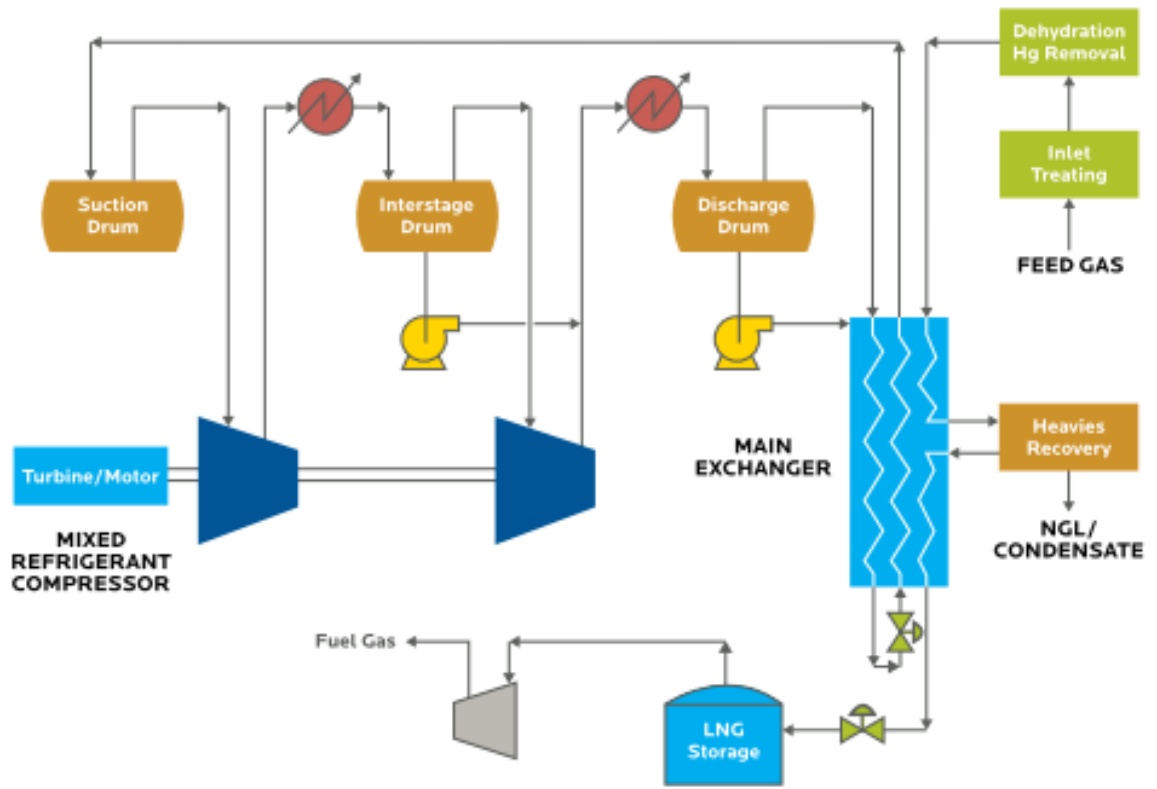

Figure 3: Mixed refrigerant

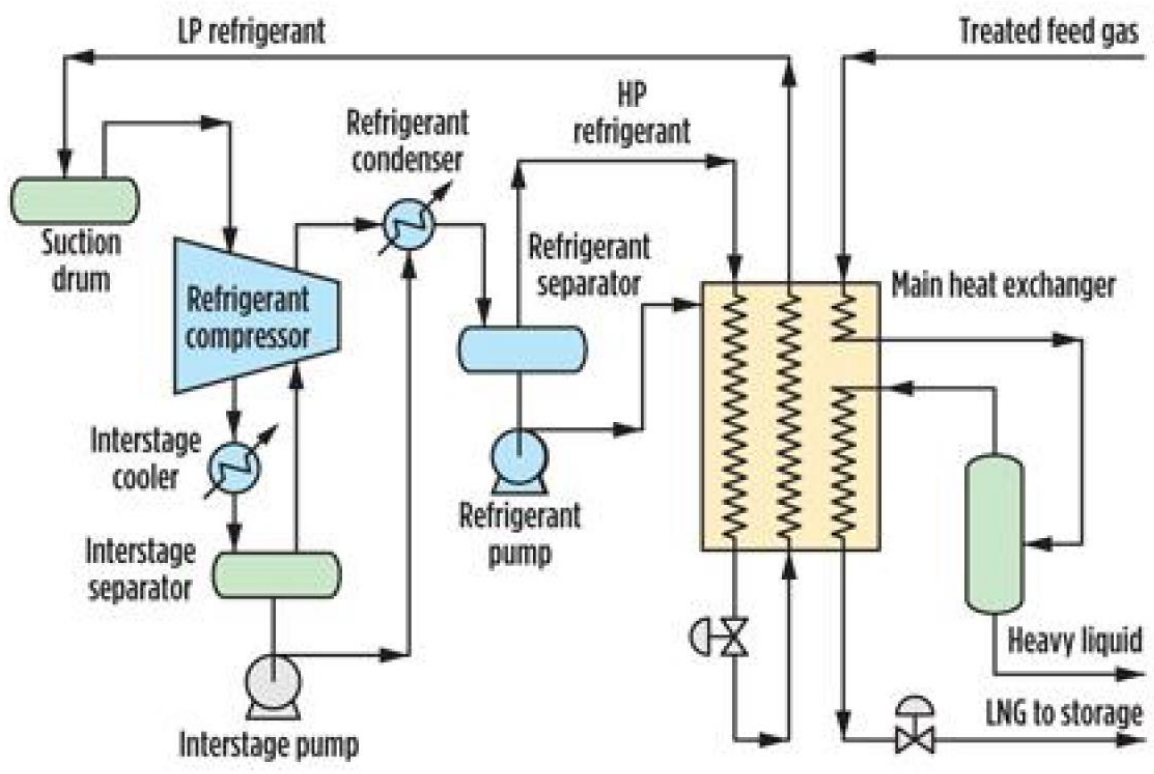

Figure 4: Single Mixed Refrigerant 
For mini and micro liquefaction with capacities in the ranges of this study (1-15 MMscf/d or 20-300 tpd), the suppliers identified are:

\begin{tabular}{l|l|l|l} 
Supplier & Name & Technology & Capacity range \\
\hline Black \& Veatch & PRICO® & Mixed refrigerant & $1-15 \mathrm{MMscf} / \mathrm{d}$ \\
\hline Chart & C100N & Nitrogen cycle & $8 \mathrm{MMscf} / \mathrm{d}$ \\
\hline Dresser-Rand & LNGoTM & $\begin{array}{l}\text { Gas compression / } \\
\text { expansion }\end{array}$ & $0.5-0.7 \mathrm{MMscf} / \mathrm{d}$ \\
\hline Galileo & Cryobox® & $\begin{array}{l}\text { Gas compression } \\
\text { expansion }\end{array}$ & $0.6-0.8 \mathrm{MMscf} / \mathrm{d}$ \\
\hline GE & LNG in a & $\begin{array}{l}\text { Salof technologies } \\
(2)\end{array}$ & $0.8-4 \mathrm{MMscf} / \mathrm{d}$ \\
\hline GE & box & $\begin{array}{l}\text { Salof technologies } \\
(2)\end{array}$ & $4-15 \mathrm{MMscf} / \mathrm{d}$ \\
\hline Linde / Cryostar & StarLiteLNG & Nitrogen cycle & $1-10 \mathrm{MMscf} / \mathrm{d}$ \\
\hline Linde & StarLNG ${ }^{\mathrm{TM}}$ & $\begin{array}{l}\text { Nitrogen cycle or } \\
\text { Mixed refrigerant }\end{array}$ & $5-15 \mathrm{MMscf} / \mathrm{d}$ \\
\hline Linde & LIMUM & \\
\hline Wartsila & MiniLNG & Mixed refrigerant & $5-15 \mathrm{MMscf} / \mathrm{d}$ \\
\hline Hamworthy & Nitrogen cycle & $1.5-15 \mathrm{MMscf} / \mathrm{d}$ \\
\hline Wartsila & NewMR & Mixed refrigerant & $<2.5 \mathrm{MMscf} / \mathrm{d}$ \\
\hline
\end{tabular}

Table 2: Mini and micro liquefaction suppliers

The most suitable technology would be selected with regard to the required capacity, the local conditions and cost.

\subsubsection{CNG}

CNG transportation aims to maximize the ratio of the weight of the transported gas to the weight of the containment hence, ideally, transport is under high pressures and low temperature conditions.

The carriage pressure usually ranges between 100 and 250 barg giving a volumetric efficiency (reduction of the gas volume at atmospheric conditions) of 150 to 300:1 (compared to LNG at approximately 600:1).

For both onshore and offshore fields, the amount of gas that can be loaded, the equipment needed and the operating procedures depend on:

- the gas composition,

- the pressure and temperature conditions at the field,

- the production rate of associated gas and thus the filling rate of the marine or land transport container, 
- the type of CNG container,

- the gas storage conditions (pressure and temperature).

At the point of delivery, the equipment needed and operating procedures depend on:

- the pressure and temperature conditions for CNG offloading,

- the possible limitation of the offloading rate,

- the required quality specification for the received gas.

In the $\mathrm{CNG}$ chain, the gas processing consists in gas compression.

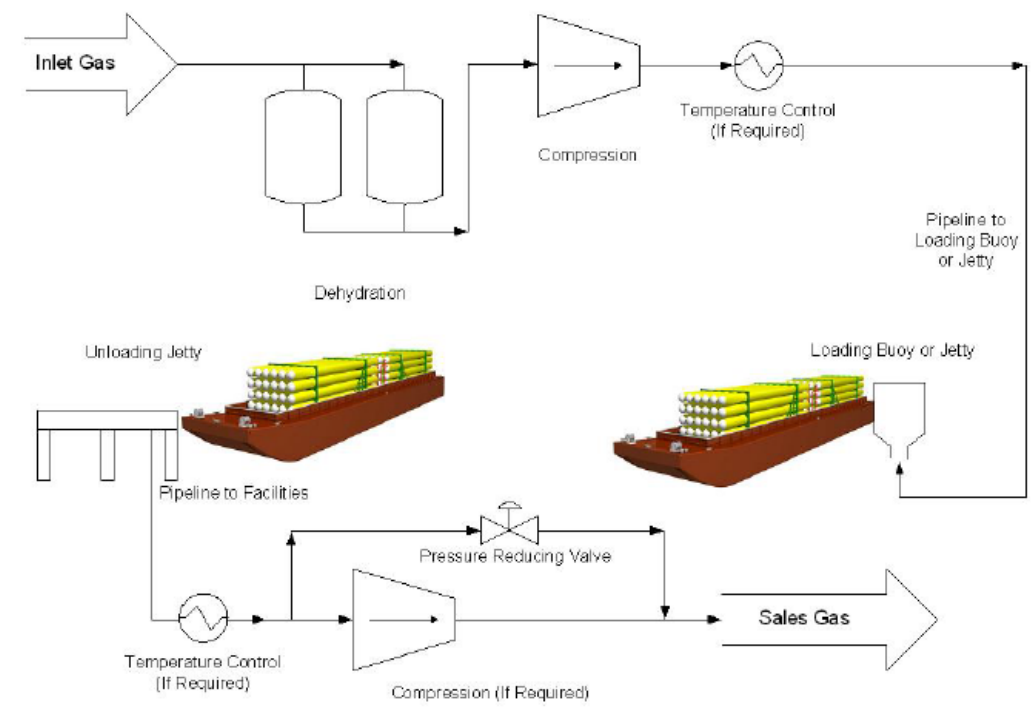

Figure 5: CNG chain

The gas compression is a mature technology and there are no specific requirements. for the compression of gas to $\mathrm{CNG}$, other than managing the pressure/temperature parameters

For the marine CNG chain however, where volumes are large, compression for loading multiple containers on the vessels is more complex and requires more careful procedures.

The main CNG concepts for process and marine transportation currently proposed are from the following suppliers (mainly transportation companies):

- Compressed Energy Technology AS (CETech),

- EnerSea-VOTRANS

- Sea NG Corporation - Coselle

- Trans Canada CNG technologies

- Knutsen

- Transocean

Of these, only EnerSea (VOTRANS) is disclosing a fit for purpose compression/loading methodology..

EnerSea (VOTRANS ${ }^{\mathrm{TM}}$ ) has a patented loading and offloading methodology which uses pressurised ethylene glycol/water solution, with a containment system consisting of several sets of storage cylinders configured into multiple tanks and tiers (two or more tanks configured to load and offload together). 


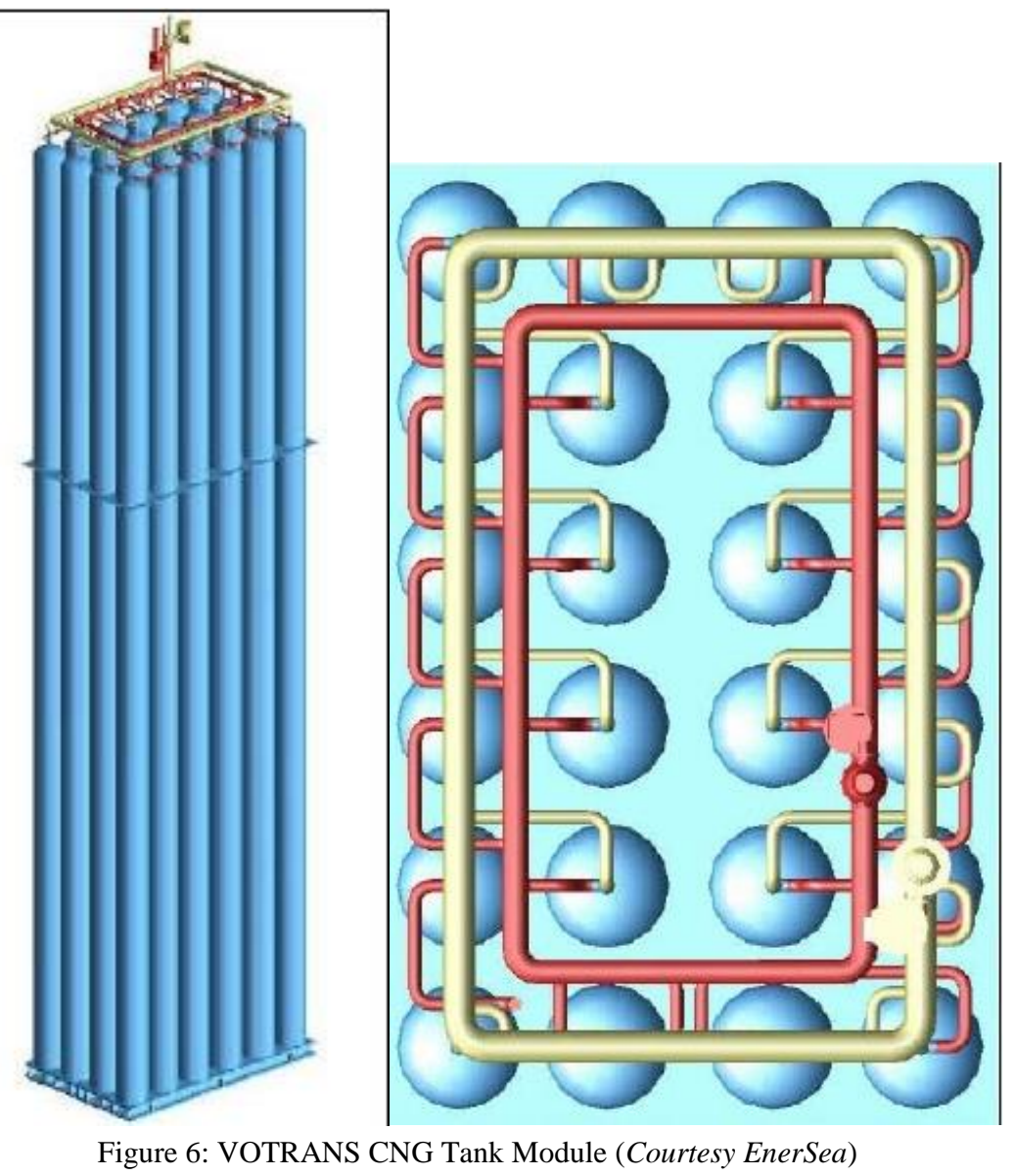

After compression and chilling, the gas flows into the ship's containment system against a pressurized ethylene glycol/water solution. Gas loading proceeds progressively from the first set of cylinder modules to the following one so cascading the glycol/water solution ahead of it. When all the modules are filled with gas, the glycol solution is stored in an insulated dedicated tank onboard the ship. The required inventory for ethylene glycol/water solution is $8-10 \%$ of the total containment system capacity.

For unloading, method is reversed, pushing the gas out using the ethylene glycol/water solution. The VOTRANS ${ }^{\mathrm{TM}}$ system has several advantages:

- the gas handling is performed at constant conditions avoiding transient situations that require careful gas conditioning and close control during operations. The gas can be maintained in a dense phase throughout loading and unloading;

- according to EnerSea, by maintaining a constant gas dense phase the VOTRANS ${ }^{\mathrm{TM}}$ system can accommodate a wide range of gas composition, including rich and associated gas;

- gas offloading rate is easily controlled by the glycol/water pumps that may deliver high, constant, rates if required;

- the fluid displacement fluid prevents gas auto-cooling in the cylinders during offloading, again allowing high offloading rates;

- liquid pumping is lower cost compared to the scavenging gas compression system needed for the blowdown method. 


\subsection{Loading and unloading}

\subsubsection{LNG}

LNG loading into ships, barges or trucks is performed using proven technology with either articulated arms or flexible cryogenic hoses.

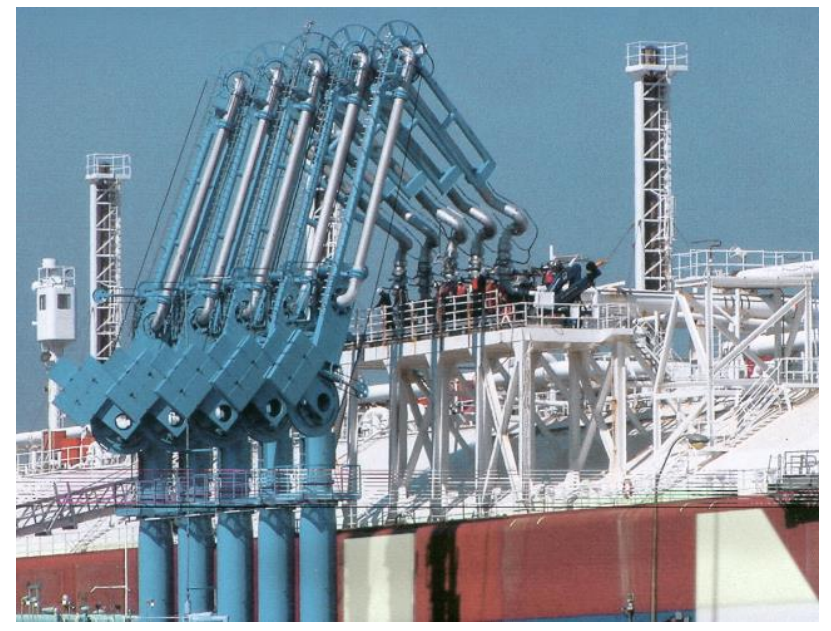

Figure 7: LNG transfer arms

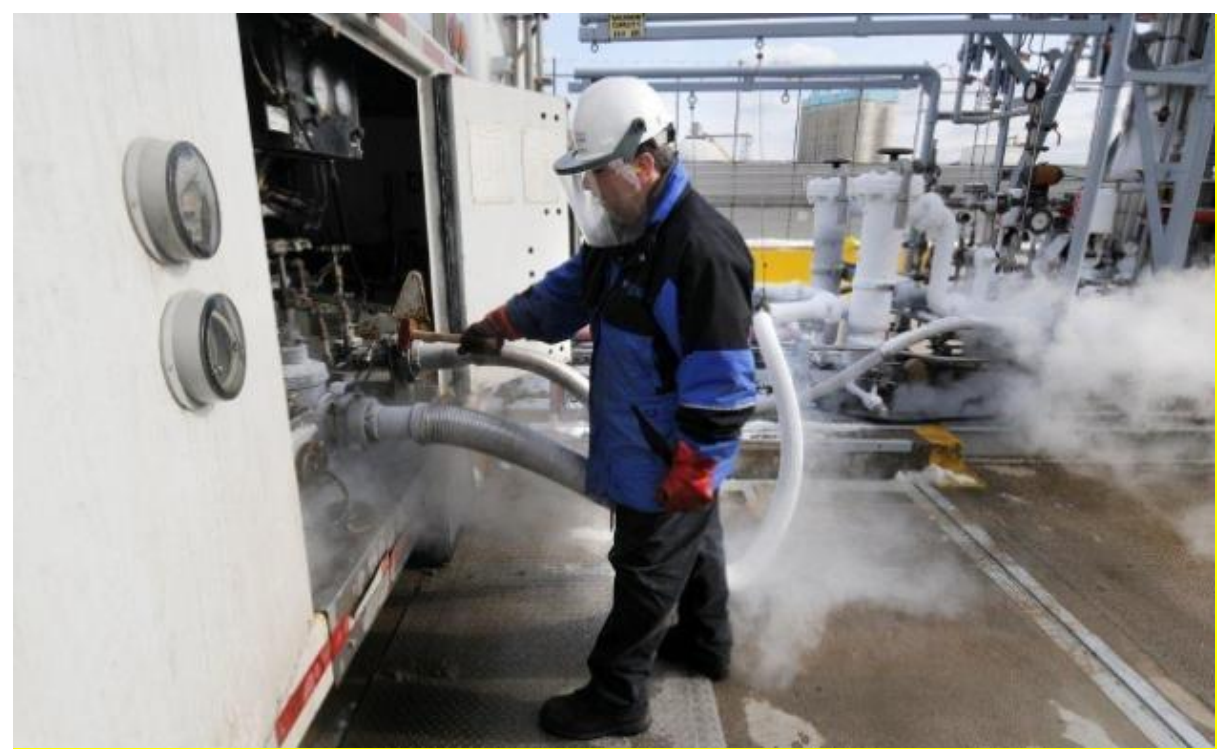

Figure 8: LNG transfer hoses

\subsubsection{CNG}

CNG loading can use high pressure flexible hoses.

CNG truck filling is common practice, but has still to be established for large quantities transferred to barges or ships. 


\subsection{Storage}

\subsubsection{LNG}

LNG storage at exporting plants provides a buffer volume to balance the gas production and transportation rates. Similarly, storage at the receiving end buffers between transportation and consumption rates.

Up to volumes of $15-20,000 \mathrm{~m}^{3}$, the LNG can be stored in pressurised vessels (bullets). The maximum individual bullet capacity is currently limited to $1,000 \mathrm{~m}^{3}$ for road transportation purposes.

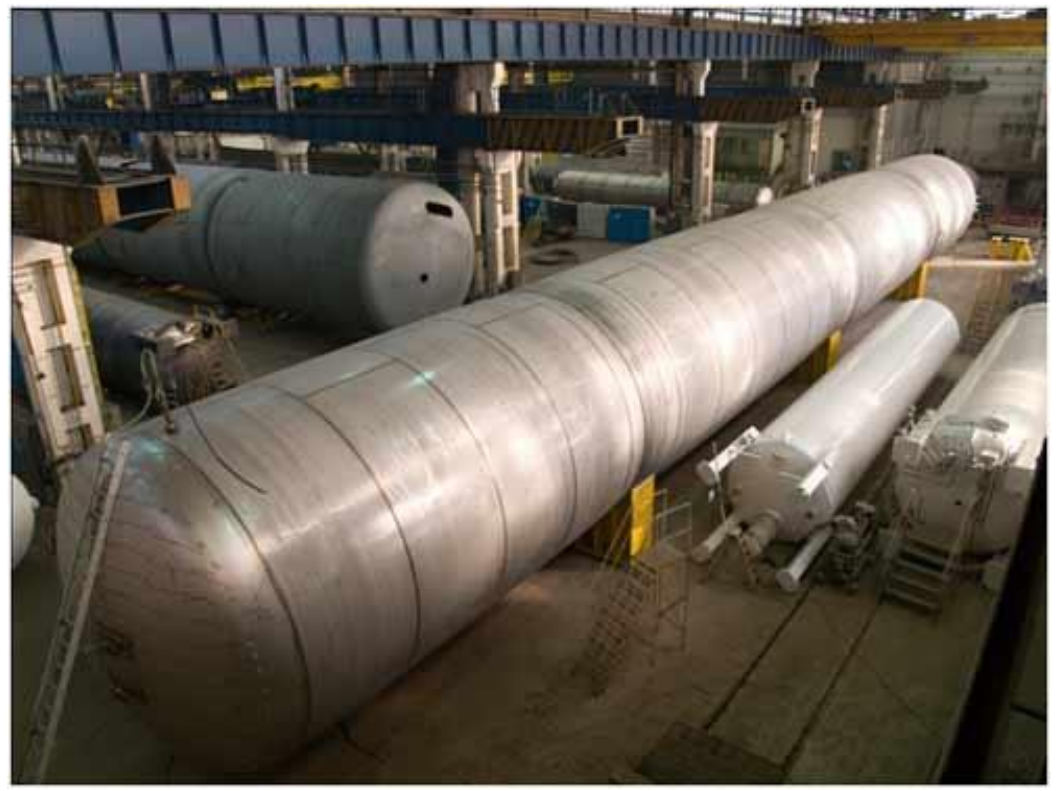

Figure 9: LNG bullets

For volumes above $15-20,000 \mathrm{~m}^{3}$, the $\mathrm{LNG}$ is normally stored in vertical cylindrical/flat bottom tanks with internal pressure lower than 0.5 barg.

\section{FULL CONTAINMENT TANK}

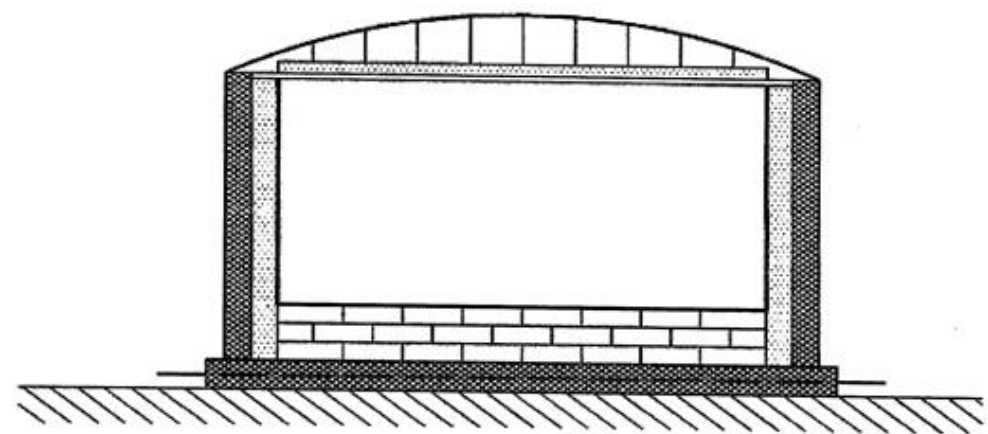

Figure 10: LNG vertical cylindrical / flat bottom tank 


\subsubsection{CNG}

CNG is directly loaded into ship, barge or trucks and distributed to consumers; at the required flow rates.

CNG transportation aims to maximize the ratio of the weight of the transported gas to the weight of the containment, hence ideally at high pressures and low temperatures. CNG is stored at high pressure (between 100 and 250 barg) in the ships, barges or trucks, and in some transport designs at temperatures down to $-30^{\circ} \mathrm{C}$. At this temperature normal (i.e. non-cryogenic) materials can still be used while the gas density is significantly higher than at ambient temperature.

Depending on the specific design, CNG containers during transport comprise pipes, cylinders, racks of cylinders, cassettes or carousels with individual capacities of a few MMscf. The total storage capacity can reach up to around 1,000 MMscf through the consolidation of the individual components.

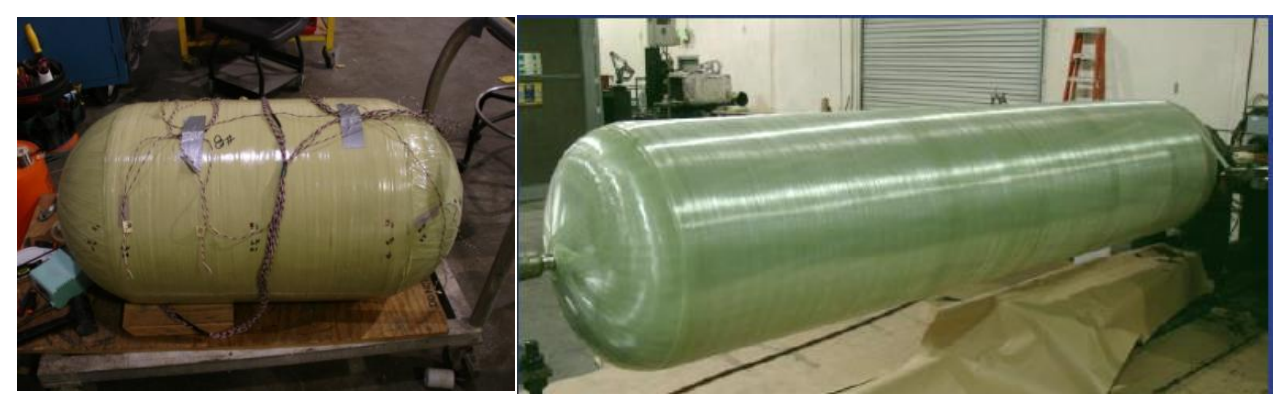

Figure 11: CNG transport cylinders

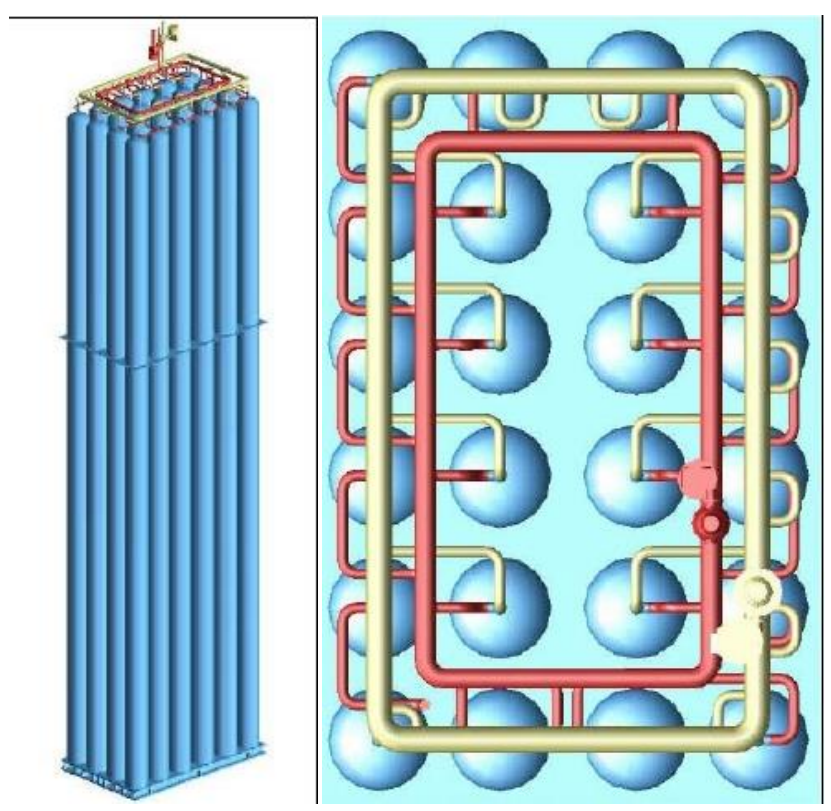

Figure 12: VOTRANS CNG Tank Module (Courtesy EnerSea) 


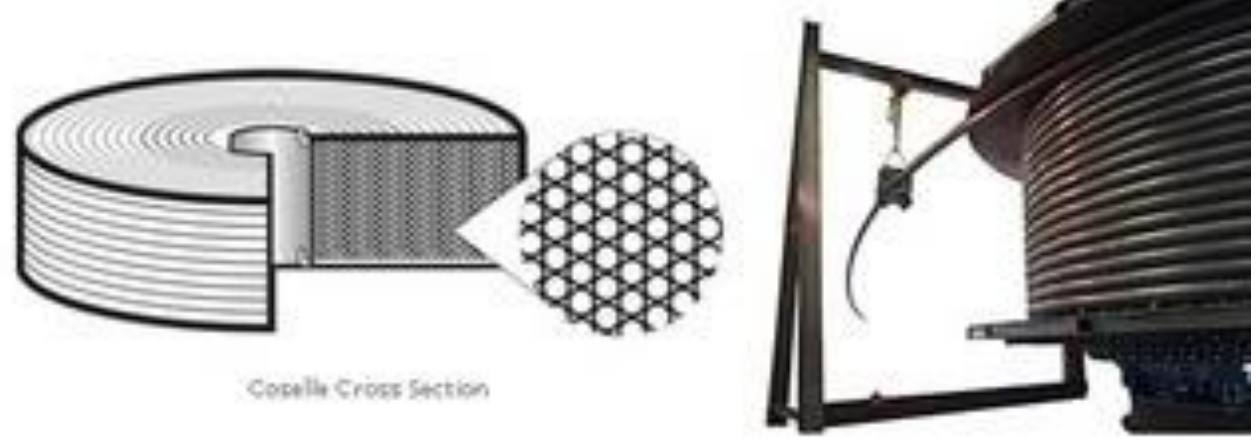

Figure 13: Coselle Cross Section (courtesy of Sea NG)

The assembly of individual containers can be made to suit the required storage capacity and transportation requirement to fit on ships, barges or trucks.

\begin{tabular}{|c|c|c|c|c|c|c|}
\hline & CETech & $\begin{array}{c}\text { EnerSea } \\
\text { VotransTM }\end{array}$ & $\begin{array}{c}\text { Sea NG } \\
\text { Corporation } \\
\text { CoselleTM }\end{array}$ & $\begin{array}{l}\text { TransCanada } \\
\text { CNG } \\
\text { Technologies }\end{array}$ & $\begin{array}{l}\text { Knutsen } \\
\text { OAS } \\
\text { Shipping }\end{array}$ & $\begin{array}{c}\text { Trans Ocean } \\
\text { Gas }\end{array}$ \\
\hline $\begin{array}{l}\text { Type of } \\
\text { Containment }\end{array}$ & $\begin{array}{l}\text { Composite or } \\
\text { X80 pipe } \\
\text { steel ; } \\
\text { composite } \\
\text { (Iso } \\
\text { container) }\end{array}$ & $\begin{array}{l}\text { X80 steel } \\
\text { cylinders }\end{array}$ & $\begin{array}{l}\text { coiled X70 } \\
\text { line pipe } \\
\text { forming a } \\
\text { carrousel } \\
\text { (Coselle) }\end{array}$ & $\begin{array}{c}\text { Composite } \\
\text { reinforced steel } \\
\text { Gas Transport } \\
\text { Modules } \\
\text { (GTM) }\end{array}$ & $\begin{array}{c}\text { X80 steel } \\
\text { cargo tank } \\
\text { cylinders } \\
\text { (CTC) }\end{array}$ & $\begin{array}{l}\text { Composite } \\
\text { HDPE and } \\
\text { fibreglass } \\
\text { cylinders } \\
\text { (MEGC) }\end{array}$ \\
\hline $\begin{array}{l}\text { Containment } \\
\text { arrangement }\end{array}$ & $\begin{array}{l}\text { Vertical or } \\
\text { horizontal } \\
\text { pipes or ISO } \\
\text { container }\end{array}$ & $\begin{array}{l}\text { Vertical } \\
\text { tank } \\
\text { modules or } \\
\text { horizontal } \\
\text { pipes }\end{array}$ & $\begin{array}{l}\text { Coselles in } \\
\text { holds of bulk } \\
\text { carrier }\end{array}$ & $\begin{array}{l}\text { GTM stacked } \\
\text { layers }\end{array}$ & $\begin{array}{l}\text { Vertically } \\
\text { stacked } \\
\text { CTC's }\end{array}$ & $\begin{array}{l}\text { Shipping } \\
\text { container or } \\
\text { modular } \\
\text { cassettes with } \\
\text { vertical } \\
\text { cylinders }\end{array}$ \\
\hline $\begin{array}{l}\text { Gas pressure } \\
\text { (barg) }\end{array}$ & $150-250$ & 125 & $200-266$ & 206 & 250 & 250 \\
\hline $\begin{array}{l}\text { Transport } \\
\text { temperature }\left({ }^{\circ} \mathrm{C}\right)\end{array}$ & $\begin{array}{c}-30 / \\
\text { ambient }\end{array}$ & $-30 / 0$ & ambient & ambient & ambient & $-30 /$ ambient \\
\hline $\begin{array}{l}\text { Cargo /Container } \\
\text { weight ratio }\end{array}$ & $\begin{array}{c}0.70 \\
\text { (composite) } \\
0.24(\mathrm{X} 80) \\
0.52 \\
\text { (container) }\end{array}$ & $0.35-0.39$ & $0.12-0.18$ & 1.5 & 0.21 & $0.34-0.47$ \\
\hline $\begin{array}{l}\text { Development } \\
\text { status }\end{array}$ & concept stage & $\begin{array}{c}\text { advanced } \\
\text { concept } \\
\text { stage }\end{array}$ & $\begin{array}{c}\text { advanced } \\
\text { concept stage }\end{array}$ & concept stage & concept stage & $\begin{array}{c}\text { Concept stage } \\
\text { for MEGC } \\
\text { container } \\
\text { only }\end{array}$ \\
\hline
\end{tabular}




\begin{tabular}{|c|c|c|c|c|c|c|}
\hline & CETech & $\begin{array}{c}\text { EnerSea } \\
\text { Votrans }^{\mathrm{TM}}\end{array}$ & $\begin{array}{c}\text { Sea NG } \\
\text { Corporation } \\
\text { Coselle }^{\mathrm{TM}}\end{array}$ & $\begin{array}{c}\text { TransCanada } \\
\text { CNG } \\
\text { Technologies }\end{array}$ & $\begin{array}{l}\text { Knutsen } \\
\text { OAS } \\
\text { Shipping }\end{array}$ & $\begin{array}{c}\text { Trans Ocean } \\
\text { Gas }\end{array}$ \\
\hline Safety & $\begin{array}{c}\text { Aframax \& } \\
\text { Suezmax } \\
\text { with gas } \\
\text { cylinders on } \\
\text { deck }\end{array}$ & $\begin{array}{l}\text { ship's holds } \\
\text { under } \\
\text { nitrogen } \\
\text { inerting }\end{array}$ & $\begin{array}{l}\text { ship's holds } \\
\text { under } \\
\text { nitrogen } \\
\text { inerting - } \\
\text { leak impact } \\
\text { limited by } \\
\text { coil diameter }\end{array}$ & $\begin{array}{l}\text { no information } \\
\text { provided }\end{array}$ & $\begin{array}{c}\text { no } \\
\text { information } \\
\text { provided }\end{array}$ & $\begin{array}{c}\text { no } \\
\text { information } \\
\text { provided }\end{array}$ \\
\hline $\begin{array}{l}\text { Ship transport } \\
\text { capacity } \\
\text { (MMscf) }\end{array}$ & $\begin{array}{c}85-319(+60 \\
\text { to } 120,000 \\
m^{3} \text { oil) } \\
200-1,200 \\
\text { variable } \\
\text { (container) }\end{array}$ & $\begin{array}{c}75-1,000 \\
\text { (ship) } \\
10-100 \\
\text { (barge) }\end{array}$ & $\begin{array}{c}51-531 \\
\text { (ship) } \\
?-80 \text { (barge) }\end{array}$ & $\begin{array}{c}12-100 \\
<1600 \\
\text { (hypothetical) }\end{array}$ & $70-1,200$ & $\begin{array}{l}\text { variable as } \\
\text { function of } \\
\text { number of } \\
\text { containers }\end{array}$ \\
\hline $\begin{array}{l}\text { Targeted market } \\
\text { (MMscf/d / } \\
\text { nautical miles) }\end{array}$ & $\begin{array}{c}49-275 / 300 \\
-2,000\end{array}$ & $\begin{array}{c}150- \\
650 / 250- \\
3,000 \text { (ship) } \\
10-100 / 50- \\
750 \text { (barge) }\end{array}$ & $\begin{array}{c}55-328 / 300- \\
1,500\end{array}$ & $10-200 /<500$ & $\begin{array}{c}100-500 / 100- \\
3,000\end{array}$ & \\
\hline Operability $^{(1)}$ & $\begin{array}{l}\text { +/- full chain } \\
\text { (except multi } \\
\text { container } \\
\text { solution) }\end{array}$ & full chain & full chain & $\begin{array}{l}\text { containment } \\
\text { concept only }\end{array}$ & full chain & $\begin{array}{l}\text { containment } \\
\text { concept only }\end{array}$ \\
\hline $\begin{array}{l}\text { Applicability to } \\
\text { associated gas } \\
\text { (1 to } 15 \text { MMscf) }\end{array}$ & $\begin{array}{c}\text { Possible } \\
\text { (combined } \\
\text { oil/gas or } \\
\text { containers) }\end{array}$ & $\begin{array}{c}\text { Possible } \\
\text { (barge) }\end{array}$ & $\begin{array}{l}\text { n.a. (ship) } \\
\text { possible } \\
\text { (barge) }\end{array}$ & Possible & Possible & Possible \\
\hline
\end{tabular}

Table 3: Summary of CNG container solutions

(1) Operability means that the solution of the technology provider covers the whole CNG transportation chain including ship configuration, gas treatment, loading and offloading operations.

\subsection{Marine transportation}

\subsubsection{LNG}

LNG has been transported by sea for over 50 years.

After a trend of increasing ship sizes - up to $265,000 \mathrm{~m} 3$ - over the past couple of decades, the new market development is promoting small ships (a few thousands thru $30,000 \mathrm{~m}^{3}$ ). These small ships are using either membrane technology or type $\mathrm{C}$ vessels to contain the LNG.

The membrane technology uses sandwich panels, comprising of insulation and a stainless steel skin, supported by the ship hull. 
SECTION

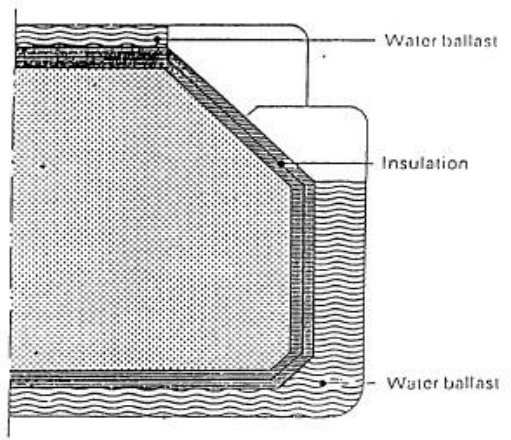

DETAIL membrain s insulation

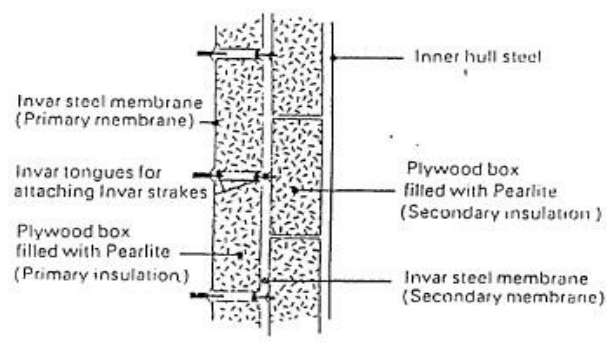

PROFILE

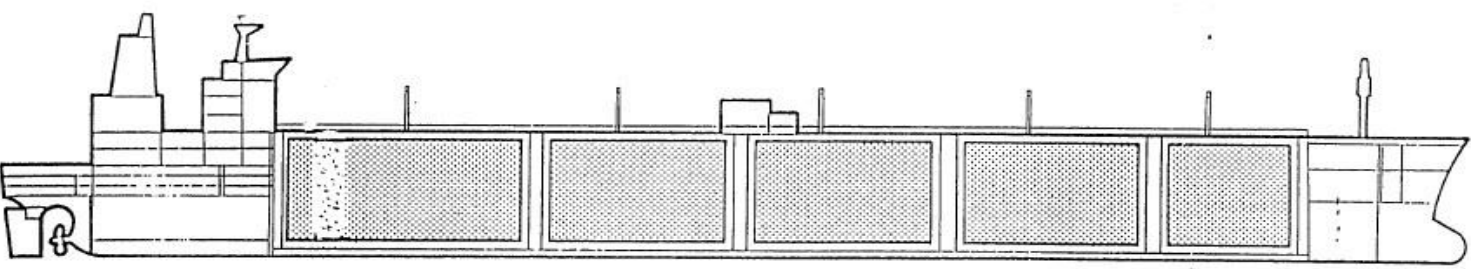

Gaz Transport Membrane Tank System

FIG 5.2.1. (1)

Figure 14: membrane type ship

The type C ship uses insulated pressurized vessels to store the LNG.

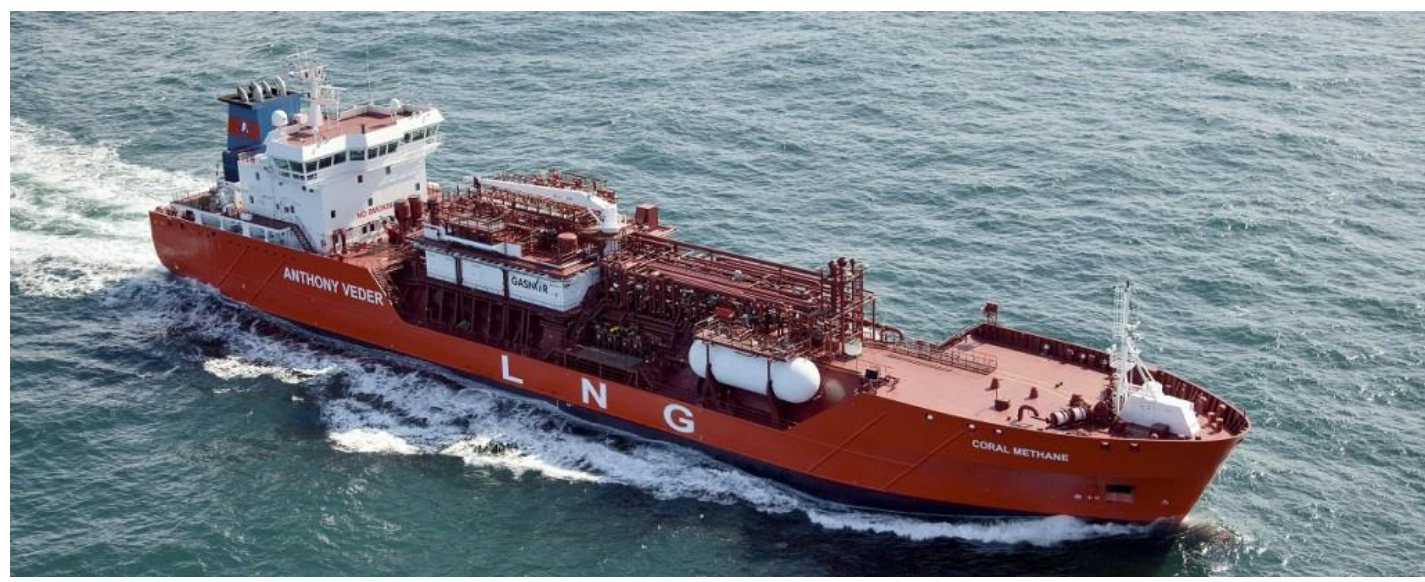

Figure 15: type C ship

\subsubsection{CNG}

The key issue is the cargo/container weight ratio. Varying from 0.12 thru 1.5, this ratio gives the ability to transport gas quantities in a defined ship size. The higher the ratio, the smaller the ship to transport a given gas volume. 
Theoretically a CNG ship could be sized to fit the gas capacity to be marketed. In practice, CNG transportation companies are often converting existing ships by adding their storage containers to provide a low-cost transport option.

The companies currently with concepts for CNG marine transportation are:

- Compressed Energy Technology AS (CETech),

- EnerSea-VOTRANS

- Sea NG Corporation - Coselle

- Trans Canada CNG technologies

- Knutsen

- Transocean

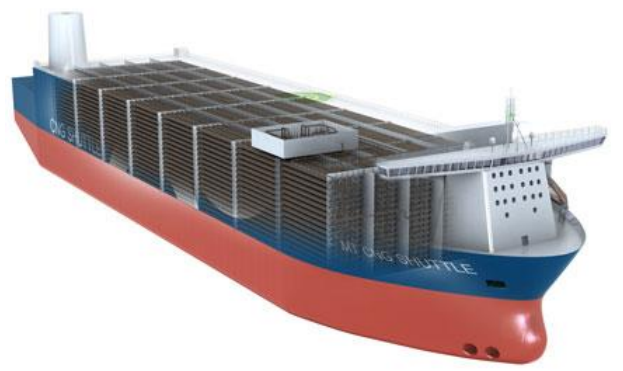

Figure 16: Courtesy of CETech

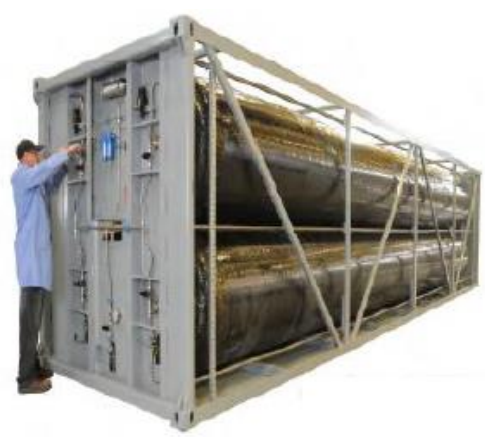

Figure 17: Titan 4 module (courtesy of CETECH) 


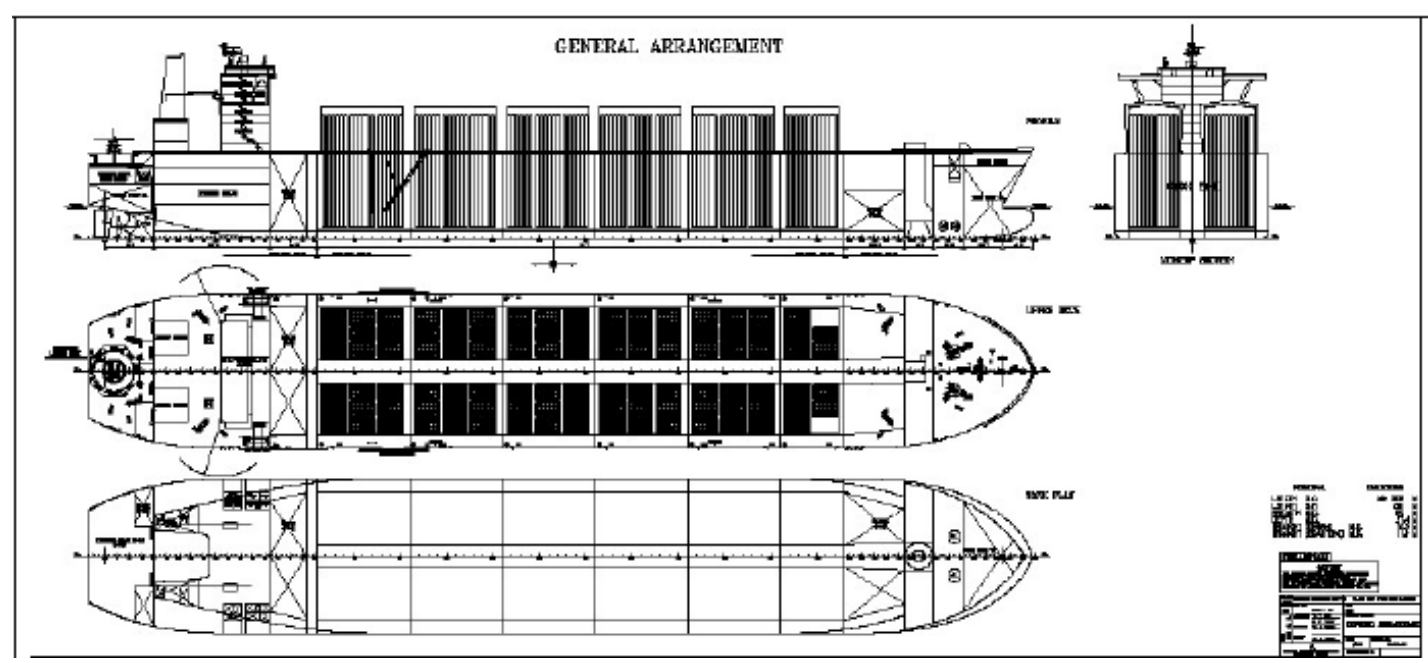

Figure 18: V-800 VOTRANSTM CNG Ship General Arrangement (Courtesy EnerSea)

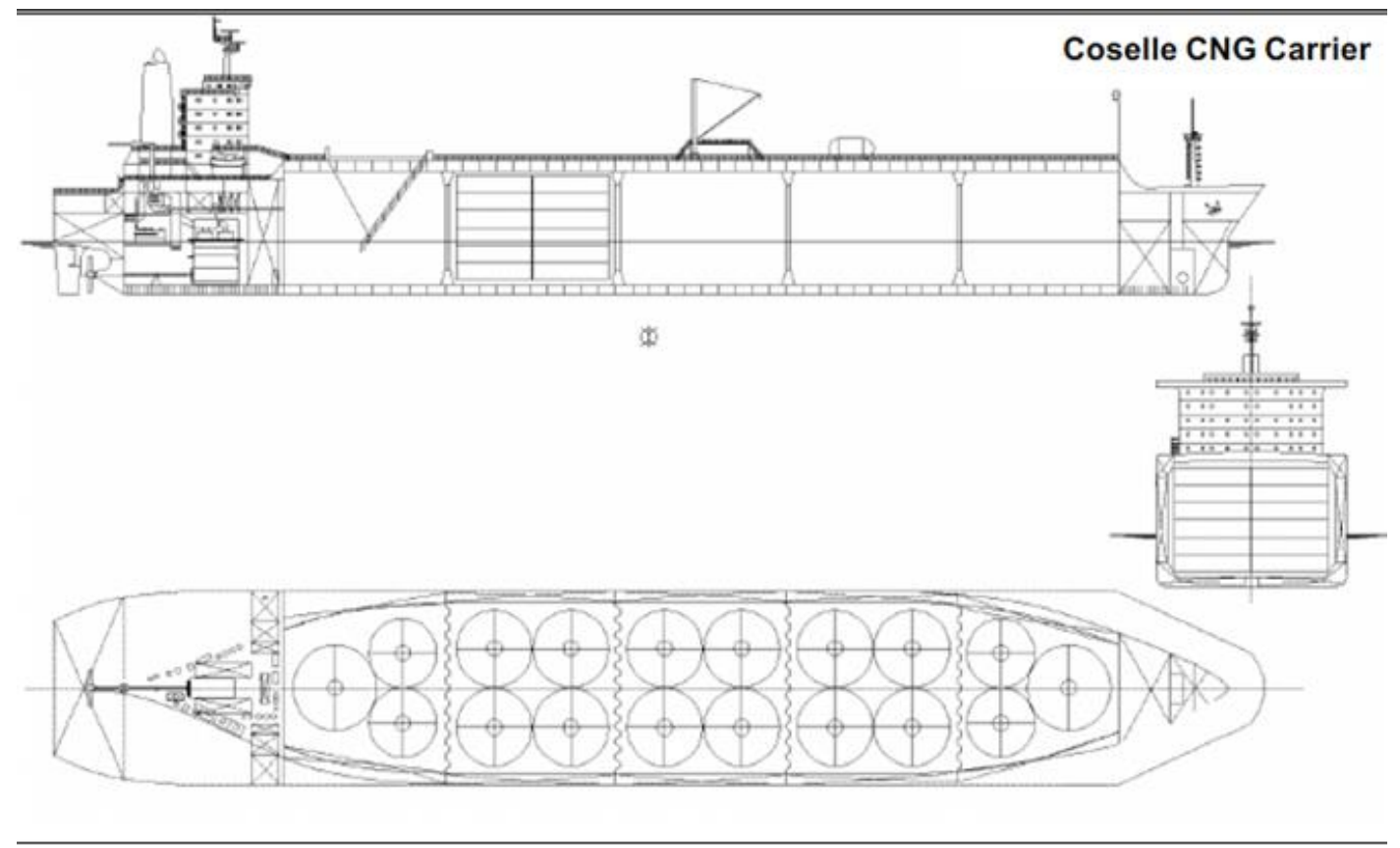

Figure 19: Coselle CNG carriers (courtesy of Sea NG)

\subsection{River transportation}

\subsubsection{LNG}

For river transportation, LNG transportation is by either barge or shallow-draught ship. The barges could be either self-propelled or an articulated tug-barge. The main technology used will be membrane or type $\mathrm{C}$ vessels. 


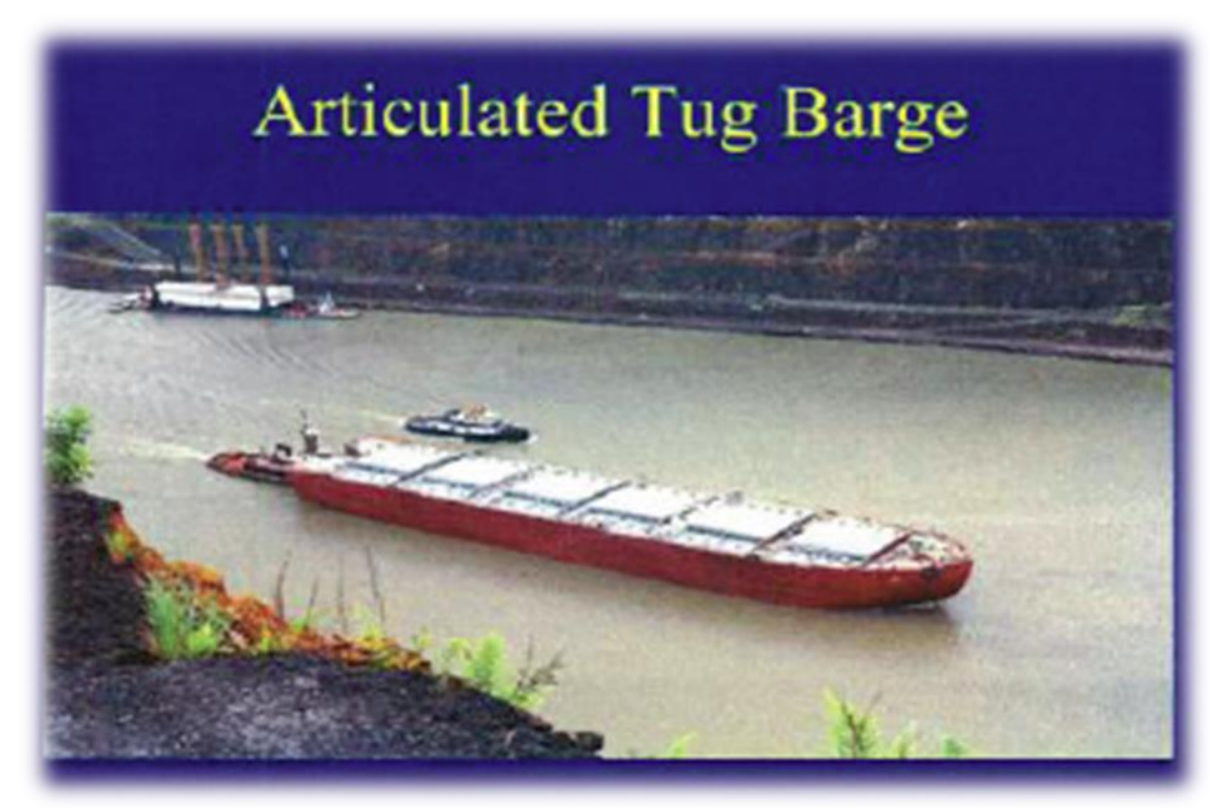

Figure 20: LNG articulated barge

\subsubsection{CNG}

CNG transportation on rivers is also by barge or shallow-draught ship, barges being either self-propelled or articulated tug-barges.

The available technologies are the same as for sea transportation but with a smaller number of individual storage containers (refer to section 5.5.2)

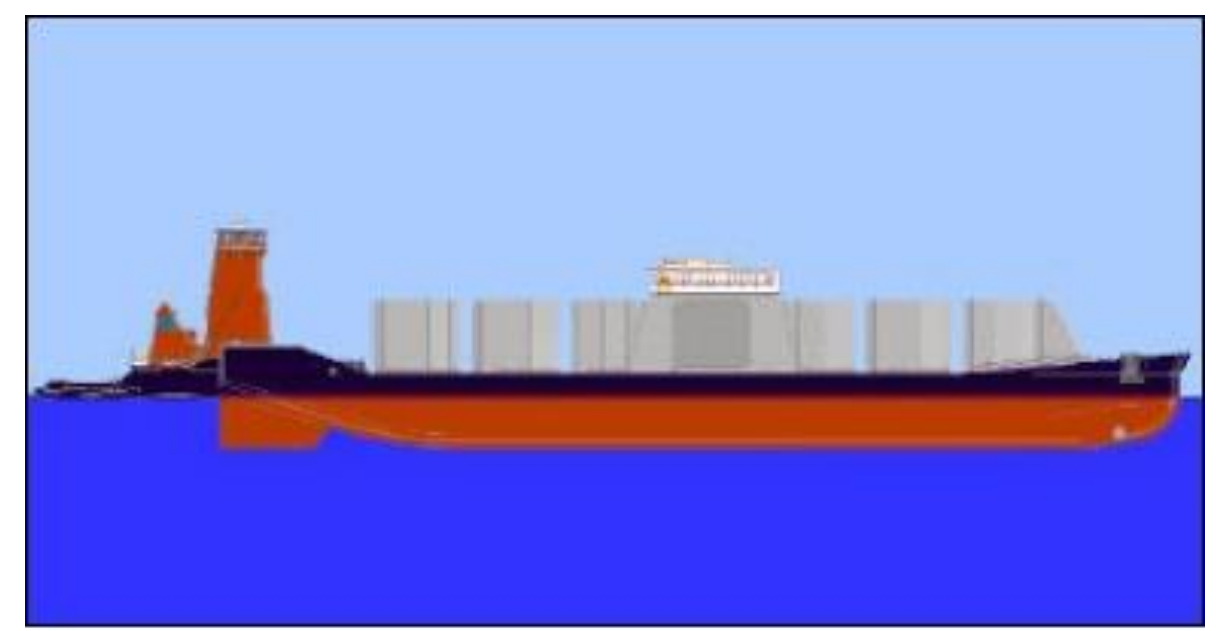

Figure 21: Coselle tug barge (Courtesy of Sea NG) 


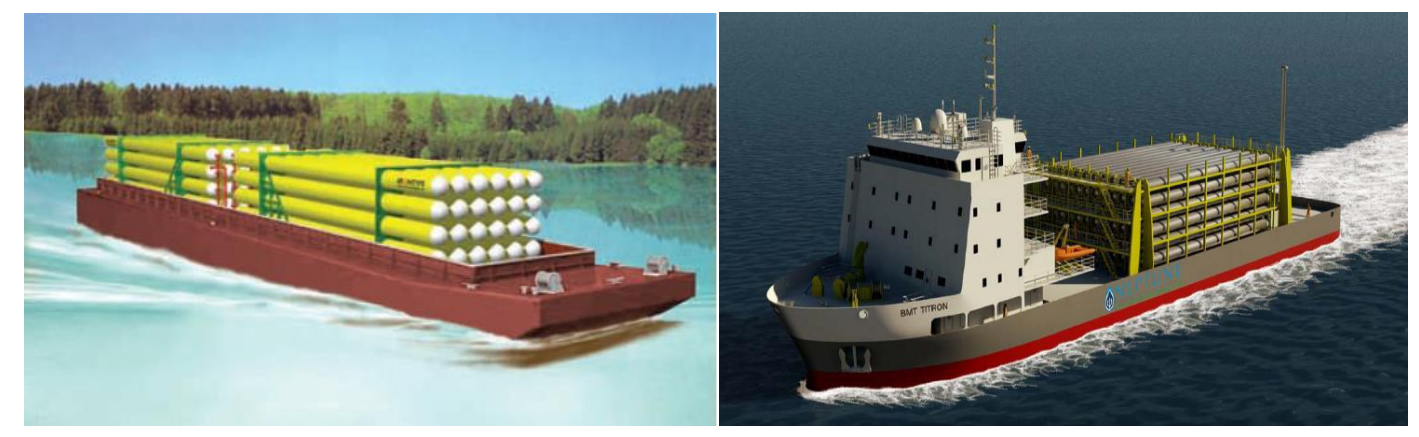

Figure 22: Shallow -draft carrier barge concept (Courtesy Transcanada)

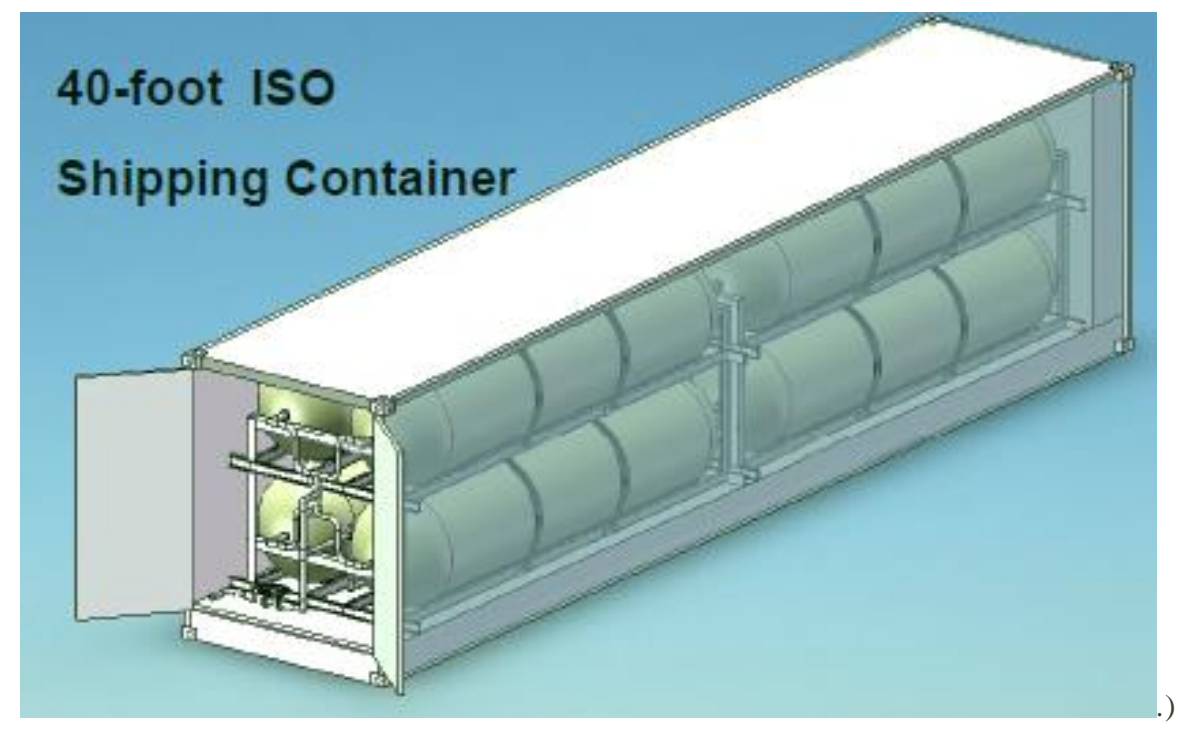

Figure 23: Standard ISO container design - (Courtesy Trans Ocean Gas Inc.)

\subsection{Truck transportation}

\subsubsection{LNG}

LNG transport by truck is a well established method.

The trucks typically transport up to 40 feet long ISO-containers, corresponding to $20 \mathrm{~T}$ of LNG. The ISO-containers are pressurised vessels with perlite-vacuum insulation allowing LNG storage for up to 3 weeks without gas venting. 


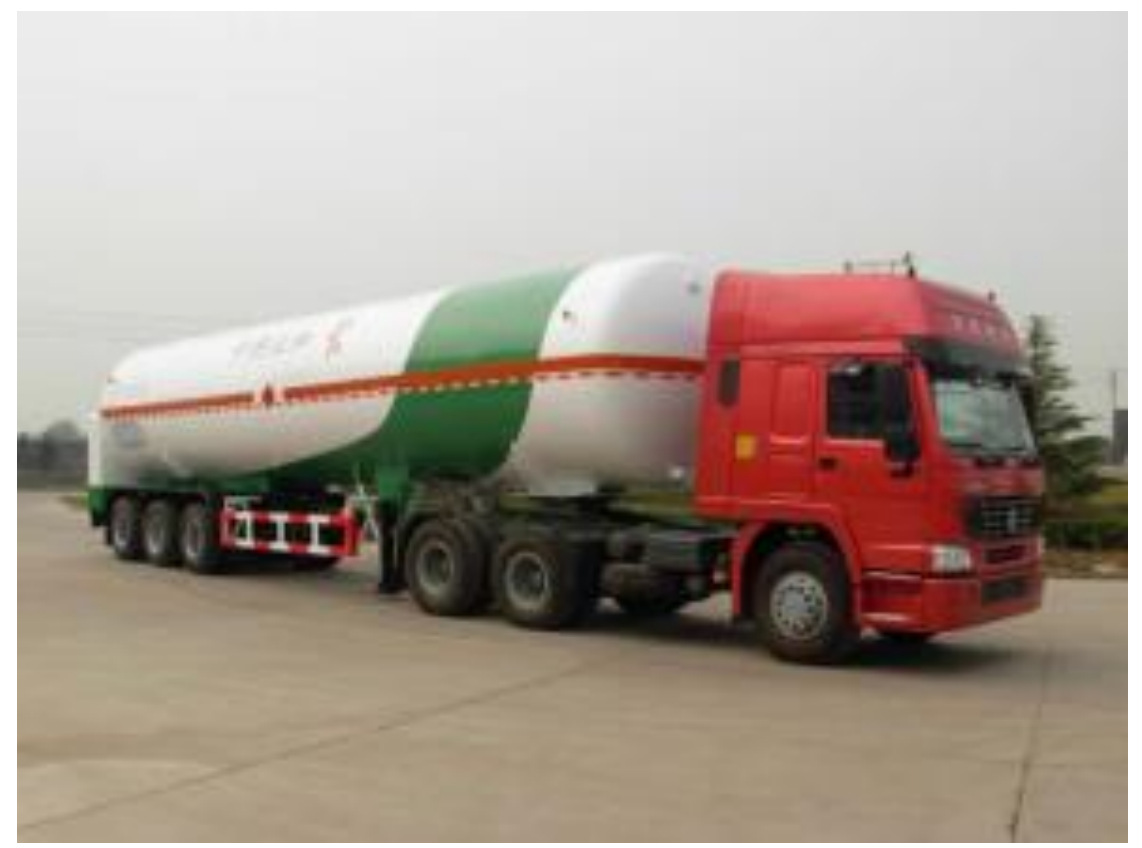

Figure 24: ISO container truck

The number of trucks and (un)loading bays that are required for LNG transportation are governed to the following parameters:

- The maximum allowed truck weight in the country, and thus the transported LNG capacity

- The maximum allowed speed of the truck

- The distance from the source to the consumer

- The loading \& unloading conditions (number of loading/unloading bays, loading/unloading rates)

- The LNG or gas consumption rate

- The working time on both sides of the chain (number of hours per day and number of days per week)

The impact of traffic regulations (maximum driving periods and imposed rest time) is not included in this analysis as it affects the number of drivers, and thus the operating costs, rather than truck numbers.

The following table shows the number of LNG trucks required for a given set of transport parameters. 


\begin{tabular}{|c|c|c|c|c|c|c|c|c|c|}
\hline & \multicolumn{3}{|c|}{$150 \mathrm{KM}$} & \multicolumn{3}{|c|}{$500 \mathrm{KM}$} & \multicolumn{3}{|c|}{$1,000 \mathrm{KM}$} \\
\hline Truck size $\mathrm{m}^{3}$ & 40 & 60 & 80 & 40 & 60 & 80 & 40 & 60 & 80 \\
\hline $\begin{array}{l}\text { Truck capacity } \\
\text { MMscf }\end{array}$ & 0.87 & 1.30 & $1 ., 73$ & 0.87 & 1.30 & 1.73 & 0.87 & 1.30 & 1.73 \\
\hline $\begin{array}{l}\text { daily gas } \\
\text { production } \\
\text { MMscf/d } \\
\end{array}$ & 15 & 15 & 15 & 15 & 15 & 15 & 15 & 15 & 15 \\
\hline $\begin{array}{l}\text { annual gas } \\
\text { production } \\
\text { MMscf/y }\end{array}$ & 5,475 & 5,475 & 5,475 & 5,475 & 5,475 & 5,475 & 5,475 & 5,475 & 5,475 \\
\hline $\begin{array}{l}\text { Driving distance } \\
\text { (km) }\end{array}$ & 150.00 & 150.00 & 150.00 & 500.00 & 500.00 & 500.00 & $1,000.00$ & $1,000.00$ & $1,000.00$ \\
\hline truck speed $(\mathrm{km} / \mathrm{h})$ & 40.00 & 40.00 & 40.00 & 40.00 & 40.00 & 40.00 & 40.00 & 40.00 & 40.00 \\
\hline travelling days & 0.16 & 0.16 & 0.16 & 0.52 & 0.52 & 0.52 & 1.04 & 1.04 & 1.04 \\
\hline $\begin{array}{l}\text { number of } \\
\text { truckloads per year }\end{array}$ & $6,094.0$ & $4,063.0$ & $3,047.0$ & $6,094.0$ & $4,063.0$ & $3,047.0$ & $6,094.0$ & $4,063.0$ & $3,047.0$ \\
\hline $\begin{array}{l}\text { number of } \\
\text { truckloads per day }\end{array}$ & 17.0 & 11.0 & 8.0 & 17.0 & 11.0 & 8.0 & 17.0 & 11.0 & 8.0 \\
\hline $\begin{array}{l}\text { total number of } \\
\text { trucks required (no } \\
\text { spare) }\end{array}$ & 7.0 & 5.0 & 4.0 & 19.0 & 13.0 & 10.0 & 37.0 & 25.0 & 19.0 \\
\hline
\end{tabular}

Table 4: LNG truck number sensitivity analysis: $15 \mathrm{MMscf} / \mathrm{d}$ gas supply

\section{LNG truck requirements: $15 \mathrm{MMscf} / \mathrm{d}$ volume}

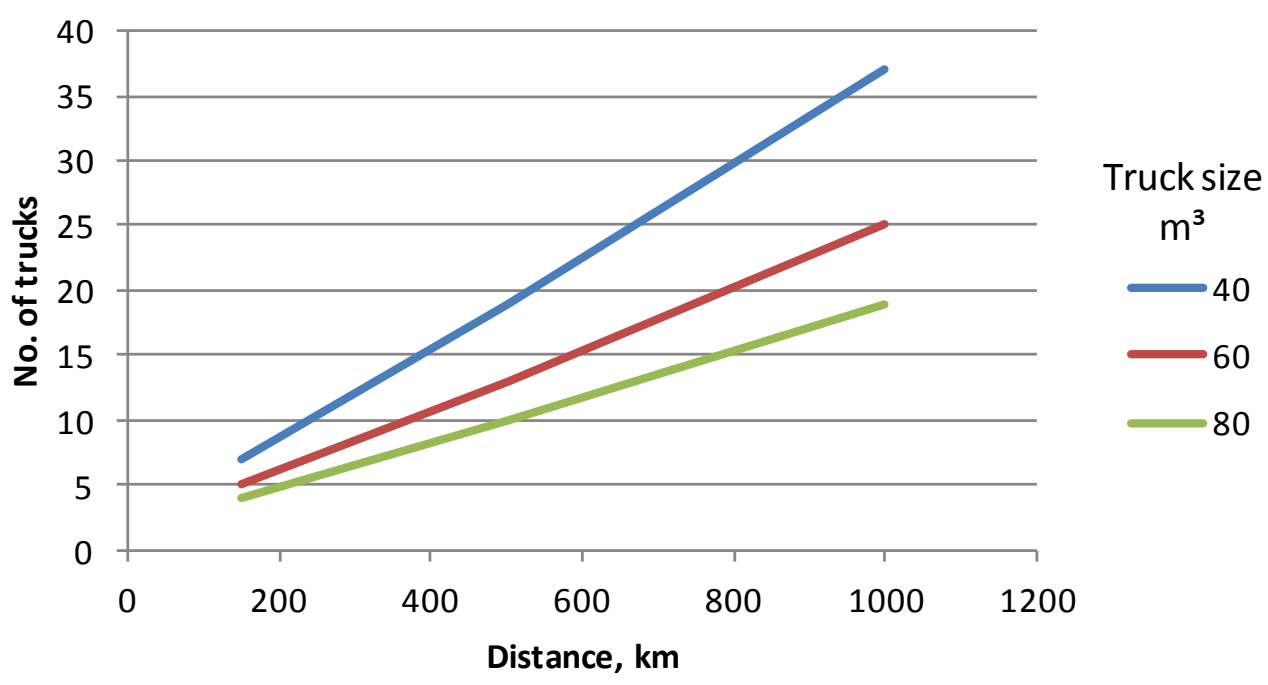

Figure 25: number of trucks versus distances

The number of bays that are required to achieve such transportation is related to the number of working hours and days per week. As an example, 1 bay is sufficient in the case of 24 hours per day and 7 days per week whilst 2 bays are required in the case of 8 hours per day and 5 days per week.

\subsubsection{CNG}

CNG is transported in cylinders assembled on trailers, or in fit-for-purpose containers (e.g. MAT $^{\circledR}$ gas storage modules from Galileo). 
The transport capacity is limited by the truck size and road weight limitations. The maximum capacity can be up to 500,000 scf at a pressure of between 200 and 250 barg.

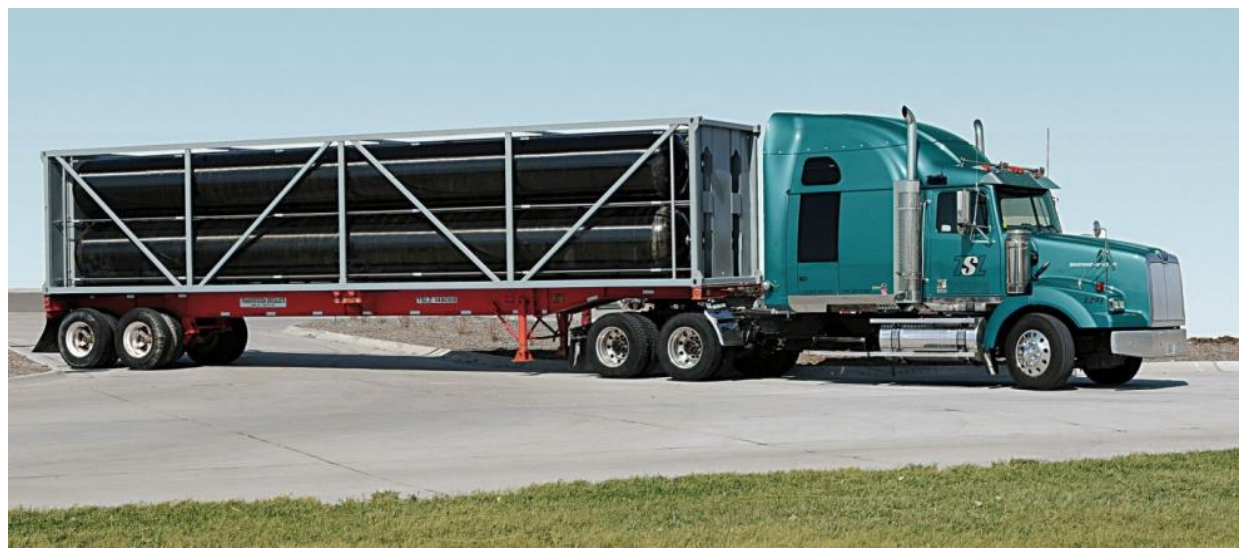

Figure 26: TITAN $^{\mathrm{TM}} 4$ Module (Courtesy Hexagon Lincoln)

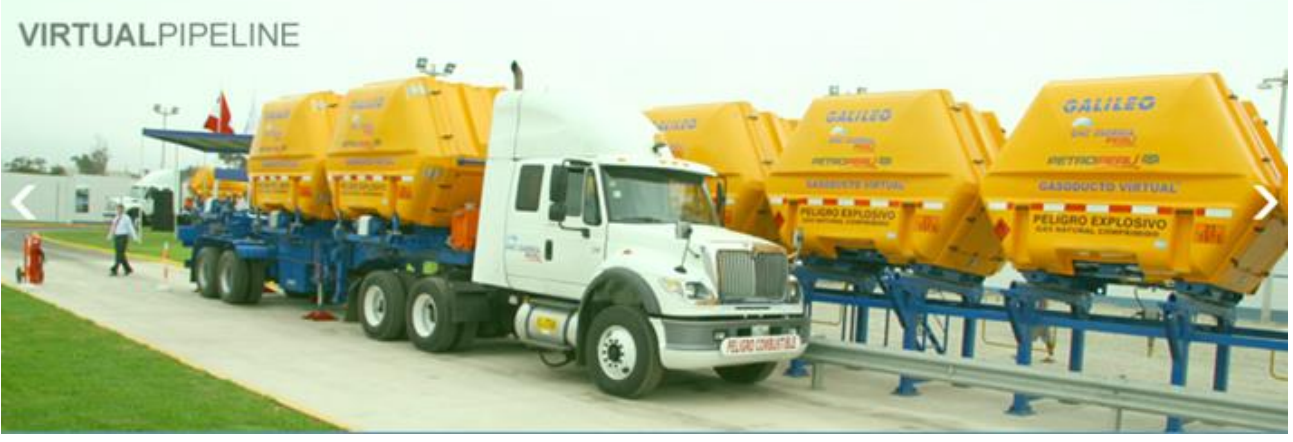

Figure 27: PAD platforms and MAT® gas storage modules (Courtesy Galileo)

In the CNG chain, the number of trucks depends on the transportation technology utilised. The following table shows the impact of the chosen technology.

The number of trucks and (un)loading bays required are governed by the same parameters as those for LNG (refer to section 5.8.1)

The following table shows the sensitivity of the number of CNG trucks from a given set of parameters. For ease of analysis only the $15 \mathrm{MMscf} / \mathrm{d}$ (300 tpd) supply will be considered. 
Table 5: CNG truck number sensitivity analysis : $15 \mathrm{MMscf} / \mathrm{d}$ gas supply

\begin{tabular}{|c|c|c|c|c|c|c|c|c|c|}
\hline \multirow[b]{2}{*}{$\begin{array}{l}\text { Truck capacity } \\
\text { MMscf }\end{array}$} & \multicolumn{3}{|c|}{$150 \mathrm{KM}$} & \multicolumn{3}{|c|}{$500 \mathrm{KM}$} & \multicolumn{3}{|c|}{$1,000 \mathrm{KM}$} \\
\hline & 0.25 & 0.36 & 0.44 & 0.25 & 0.36 & 0.44 & 0.25 & 0.36 & 0.44 \\
\hline $\begin{array}{l}\text { daily gas } \\
\text { production } \\
\text { MMscf/d }\end{array}$ & 15 & 15 & 15 & 15 & 15 & 15 & 15 & 15 & 15 \\
\hline $\begin{array}{l}\text { yearly gas } \\
\text { production } \\
\text { MMscf/y }\end{array}$ & 5,475 & 5,475 & 5,475 & 5,475 & 5,475 & 5,475 & 5,475 & 5,475 & 5,475 \\
\hline truck speed $(\mathrm{km} / \mathrm{h})$ & 40.00 & 40.00 & 40.00 & 40.00 & 40.00 & 40.00 & 40.00 & 40,00 & 40.00 \\
\hline travelling days & 0.16 & 0.16 & 0.16 & 0.52 & 0.52 & 0.52 & 1.04 & 1,04 & 1.04 \\
\hline $\begin{array}{l}\text { number of trucks } \\
\text { per year }\end{array}$ & $21,900.0$ & $15,209.0$ & $12,444.0$ & $21,900.0$ & $15,209.0$ & $12,444.0$ & $21,900.0$ & $15,209.0$ & $12,444.0$ \\
\hline $\begin{array}{l}\text { number of trucks } \\
\text { per day }\end{array}$ & 60.0 & 42.0 & 34.0 & 60.0 & 42.0 & 34.0 & 60.0 & 42.0 & 34.0 \\
\hline
\end{tabular}

\section{CNG truck requirements: $15 \mathrm{MMscf} / \mathrm{d}$ volume}

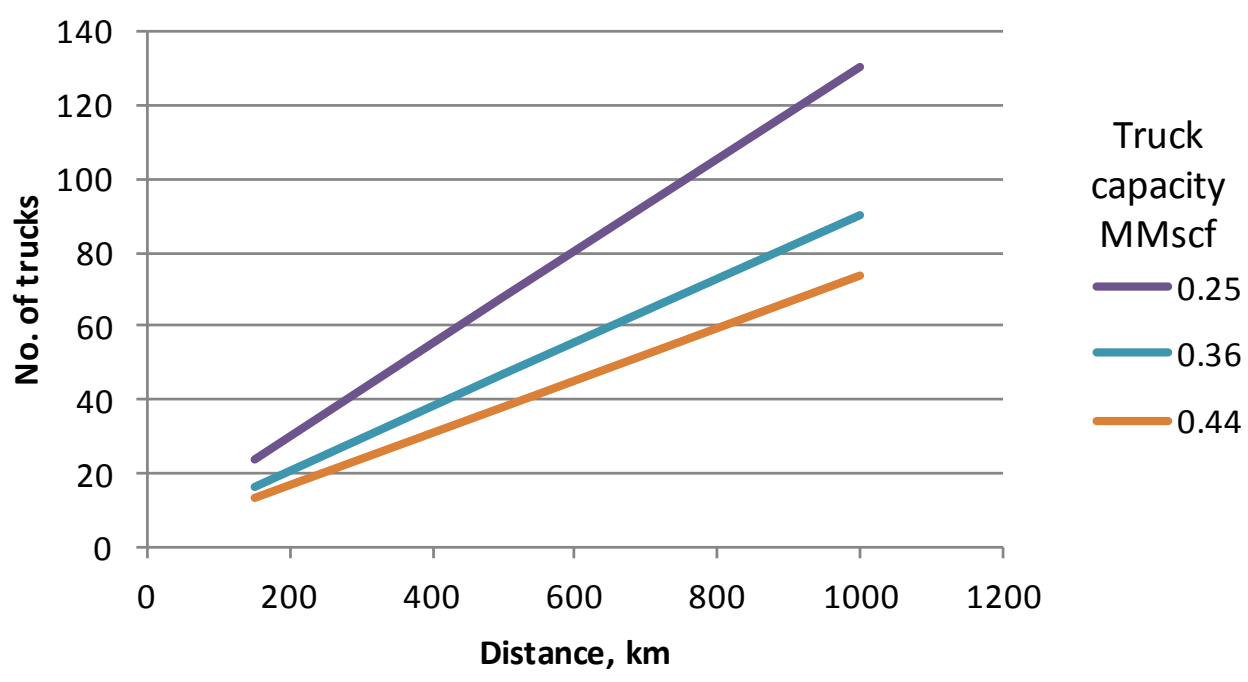

Figure 28: number of CNG trucks versus distances

The number of trucks becomes important when the distance exceeds $800 \mathrm{~km}$. The required truck fleet and the number of loading bays will limit the realistic distance within which CNG could be dispatched. 
In the CNG chain, the number of trucks depends also on the transportation technology utilised. The following table shows the impact of the chosen technology.

\begin{tabular}{|c|c|c|c|c|}
\hline & \multicolumn{4}{|c|}{$1 \mathrm{MMscf} / \mathrm{d}$} \\
\hline Trailer type & Tube trailer & Luxfer-GTM & $\begin{array}{l}\text { Lincoln } \\
\text { TITAN }\end{array}$ & Galileo \\
\hline Capacity (scf) & 290,000 & 440,000 & 360,000 & 250,000 \\
\hline \multirow[t]{2}{*}{ No. to load/day } & 4 & 3 & 3 & 4 \\
\hline & \multicolumn{4}{|c|}{5 MMscf/d } \\
\hline Trailer type & Tube trailer & Luxfer-GTM & $\begin{array}{l}\text { Lincoln } \\
\text { TITAN }\end{array}$ & Galileo \\
\hline Capacity (scf) & 290,000 & 440,000 & 360,000 & 250,000 \\
\hline \multirow[t]{2}{*}{ No. to load/day } & 18 & 12 & 14 & 20 \\
\hline & \multicolumn{4}{|c|}{10 MMscf/d } \\
\hline Trailer type & Tube trailer & Luxfer-GTM & $\begin{array}{l}\text { Lincoln } \\
\text { TITAN }\end{array}$ & Galileo \\
\hline Capacity (scf) & 290,000 & 440,000 & 360,000 & 250,000 \\
\hline \multirow[t]{2}{*}{ No. to load/day } & 35 & 23 & 28 & 40 \\
\hline & \multicolumn{4}{|c|}{$15 \mathrm{MMscf} / \mathrm{d}$} \\
\hline Trailer type & Tube trailer & Luxfer-GTM & $\begin{array}{l}\text { Lincoln } \\
\text { TITAN }\end{array}$ & Galileo \\
\hline Capacity (scf) & 290,000 & 440,000 & 360,000 & 250,000 \\
\hline No. to load/day & 52 & 35 & 42 & 60 \\
\hline
\end{tabular}

\subsection{Utilisation of LNG and CNG}

\subsubsection{General}

The utilisation of the LNG or CNG will depend upon the consumer requirements. The LNG chain delivers either LNG and/or gas to consumers, whilst the CNG chain can deliver either $\mathrm{CNG}$ or gas to consumers

\subsubsection{LNG utilisation}

The LNG will be either vaporised for use in gaseous form at the required pressure, or used as LNG for bunkering or fuelling.

For bunkering and fuelling stations, the LNG will be transferred either to buffer drums or directly to the LNG dispensers.

In case of consumption in gaseous form, the utilisation process will use a typical LNG terminal process. 


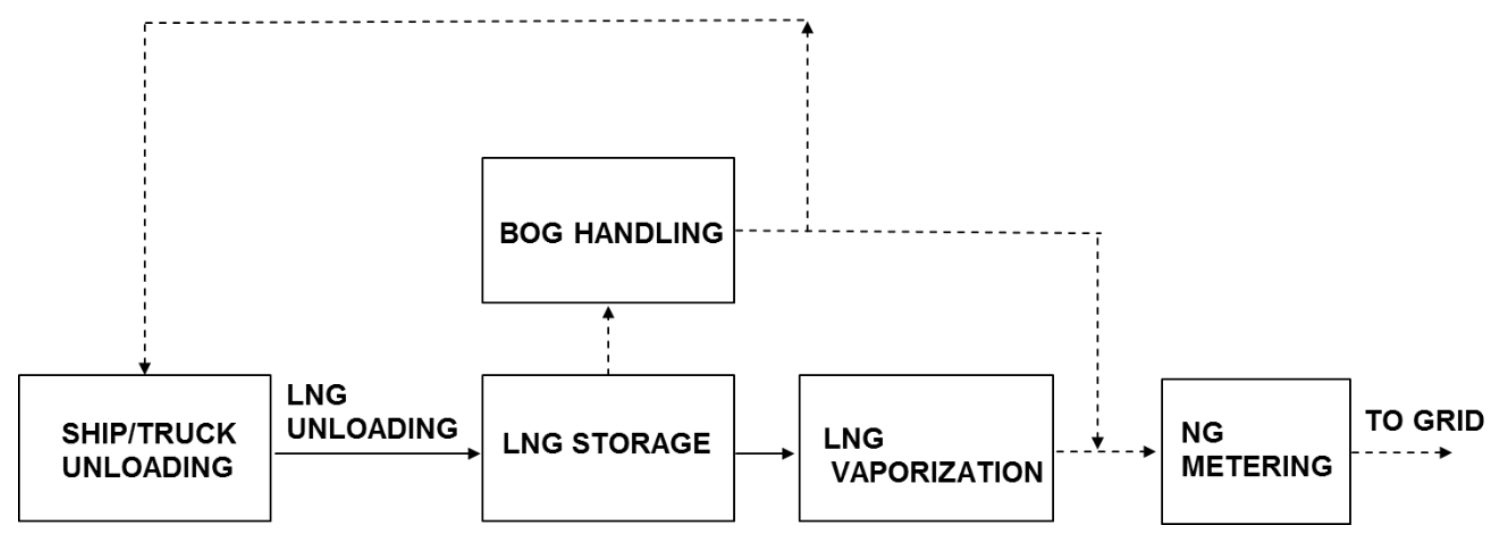

Figure 29: Vaporisation block diagram

For LNG conversion to gas there are four main types of vaporizers:

- An Open rack vaporizer (ORV) which uses sea/river water as the heat source is composed of panel-shaped heat transfer tubes. LNG flows upward inside the finned heat transfer tubes, while water flows down along the outer surface of the tubes.

- A Submerged combustion vaporizer (SCV) is a fired heat source LNG vaporizer using low pressure fuel gas coming from the boil-off gas system. The SCV uses a heat transfer coil installed in a water bath, with the liquid LNG flowing inside the coil. The conventional vaporizer is equipped with submerged gas combustion burners firing into the water bath.

- A Shell and Tube vaporizer (STV) or Intermediate Fluid Vaporiser (IFV) uses a liquid as the heating medium to vaporise the LNG. The LNG flows through multiple tubes and the heating fluid enters in the shell surrounding the tubes. If an open loop system is used, sea/river water is used as the heating fluid. If a closed loop system is used, a variety of fluids can be used: glycol, water, propane, etc.

- An Ambient Air vaporizer (AAV) uses air as the heating medium, either with natural or forced draft.
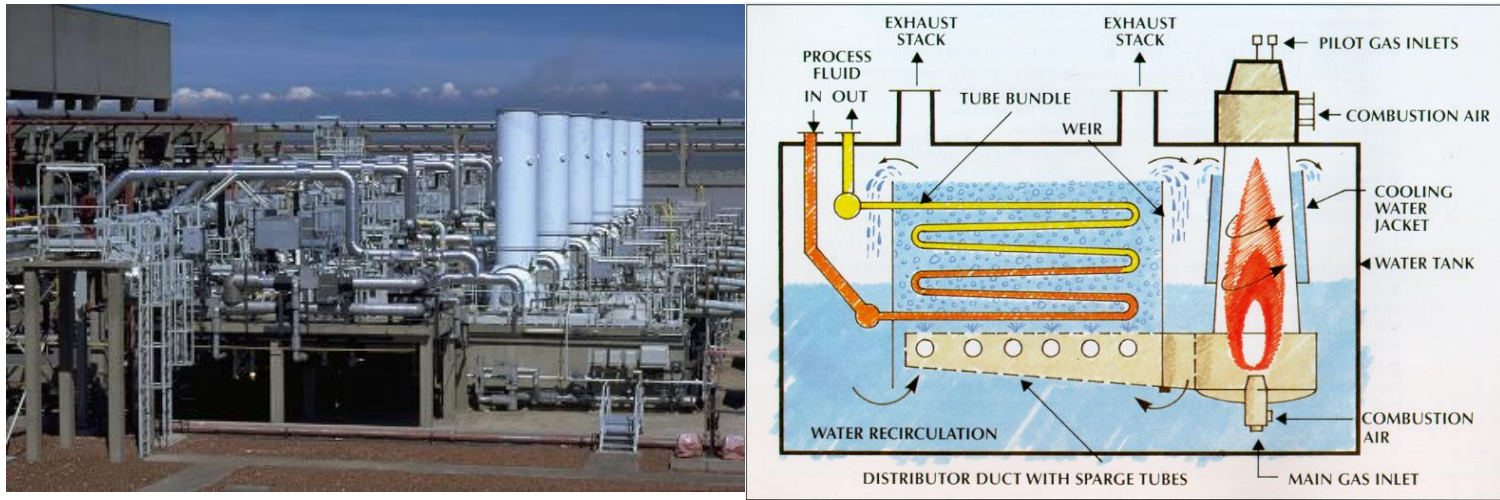

Figure 30: SCV 

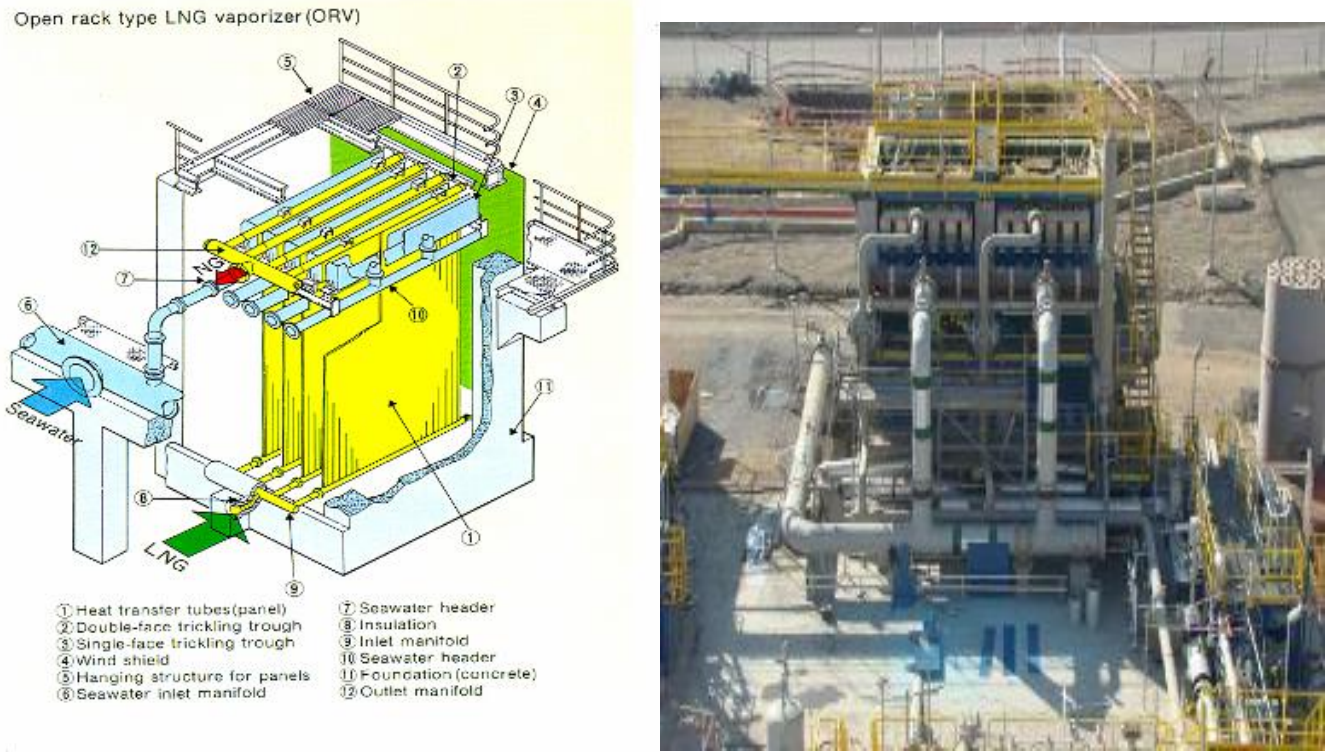

Figure 31: ORV

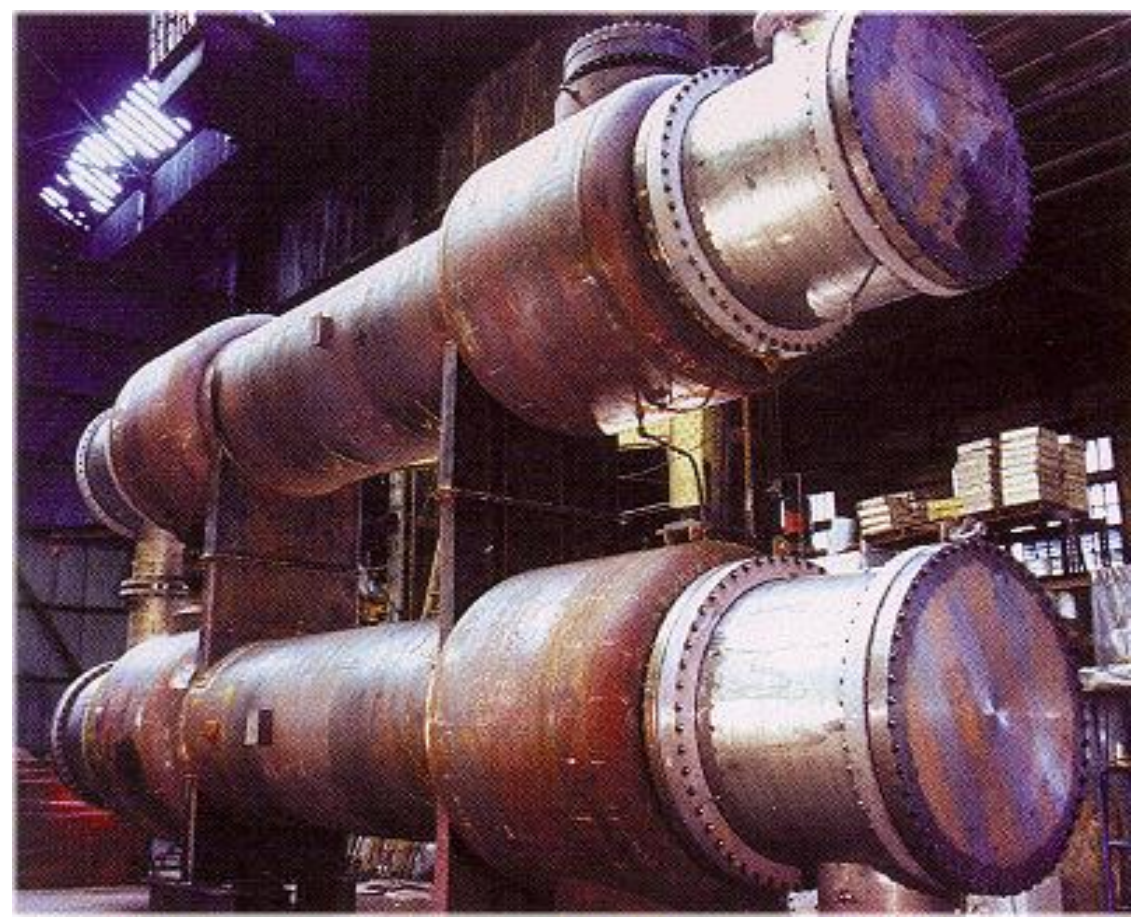

Figure 32: STV 

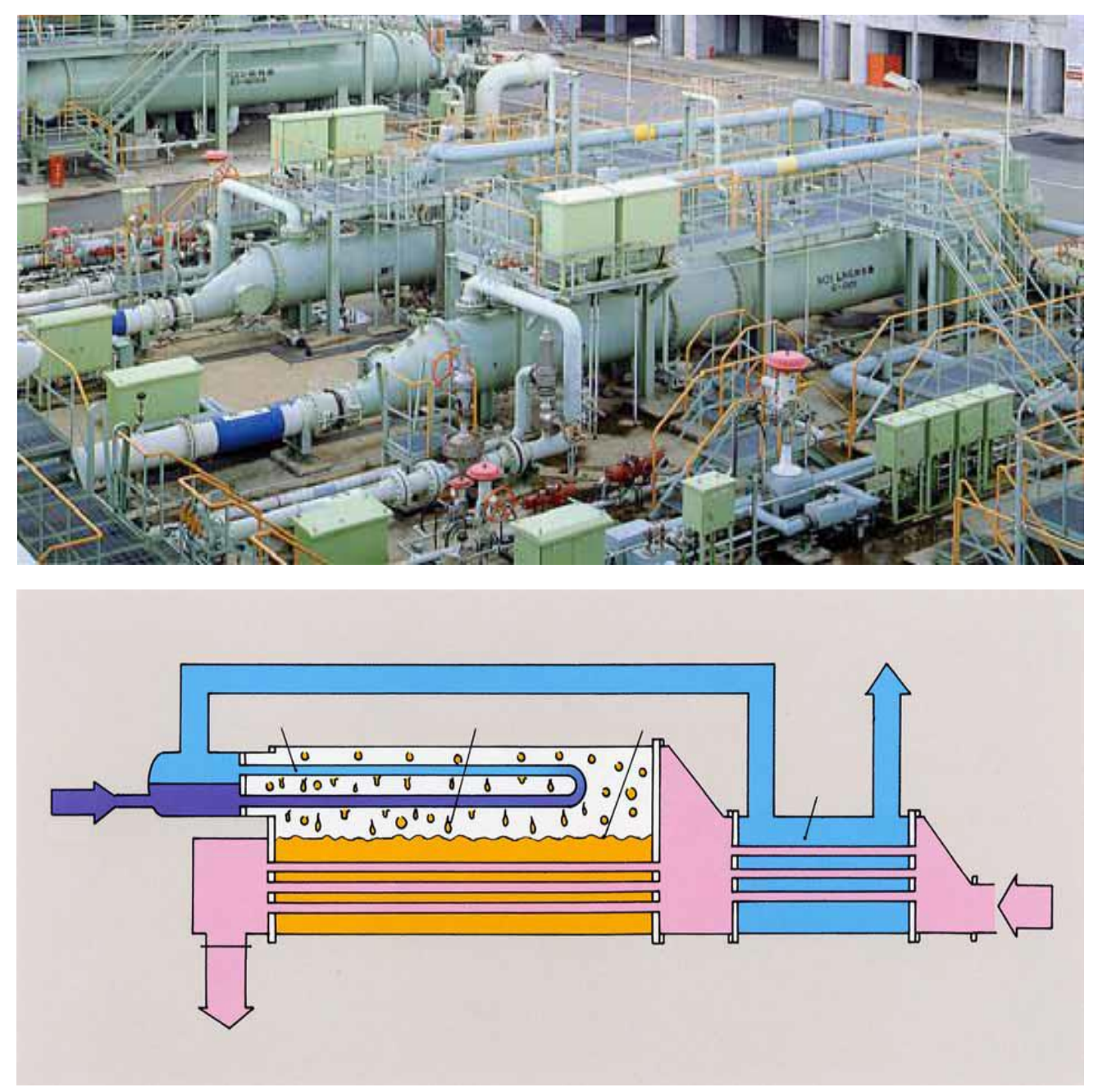

Figure 33: IFV 


\begin{tabular}{|c|c|c|}
\hline Type of vaporizer & Advantages & Disadvantages \\
\hline ORV & $\begin{array}{l}\text { - Low vaporization cost, only } \\
\text { OPEX for sea water pumps } \\
\text { - Used worldwide and proven } \\
\text { technology for base load } \\
\text { LNG terminal }\end{array}$ & $\begin{array}{l}\text { - Sea water system CAPEX } \\
\text { - ORV coating (required every } 5 \\
\text { years on average) } \\
\text { - Water release impact (cold water } \\
\text { release) in flora and fauna } \\
\text { - Sea water shall be chlorinated to } \\
\text { avoid bio-fouling and de- } \\
\text { chlorinated before releasing to the } \\
\text { sea } \\
\text { - Sea water quality as per vendor } \\
\text { recommendation (solids, heavy } \\
\text { metals, etc. removal) } \\
\text { - Regular maintenance of sea water } \\
\text { pumps }\end{array}$ \\
\hline SCV & $\begin{array}{l}\text { - Lower investment cost } \\
\text { than ORV } \\
\text { - More flexibility under any } \\
\text { conditions } \\
\text { - Possible to combine with } \\
\text { cogeneration system, which } \\
\text { offers a reduction in energy } \\
\text { consumption and lower } \\
\text { emissions. }\end{array}$ & $\begin{array}{l}\text { - High operating cost due to the gas } \\
\text { consumption for the burners }(1.3 \% \\
\text { of total send-out) } \\
\text { - High emissions due to } \\
\text { combustion of gas (NOx, CO2) } \\
\text { - Requires a dedicated fuel gas } \\
\text { system }\end{array}$ \\
\hline STV/IFV & $\begin{array}{l}\text { - Lower investment cost } \\
\text { than ORV if open loop } \\
\text { - Lower maintenance than } \\
\text { ORV if close loop }\end{array}$ & $\begin{array}{l}\text { - Open loop: } \\
\text { • Sea water release as in } \\
\text { ORV: temperature and } \\
\text { chlorine content, } \\
\text { - Close loop } \\
\text { - Water glycol, risk of } \\
\text { spillage and contamination } \\
\text { - Higher OPEX for ambient } \\
\text { air heaters and water pumps } \\
\text { than ORV } \\
\text { - Requires a stable LNG and } \\
\text { water flow to avoid icing }\end{array}$ \\
\hline AAV & -OPEX essentially nil & - Higher CAPEX \\
\hline
\end{tabular}




\begin{tabular}{|c|c|c|}
\hline Type of vaporizer & Advantages & Disadvantages \\
\hline & $\begin{array}{l}\text {-Maintenance nil, no } \\
\text { corrosion, no erosion } \\
\text { • No external coating is } \\
\text { required } \\
\text {-Zero emissions, zero } \\
\text { releases }\end{array}$ & $\begin{array}{l}\text { - Large footprint } \\
\text { - Distance between tube banks must } \\
\text { be a minimum } 4.5 \text { meters to avoid } \\
\text { cold air recirculation } \\
\text { - If large number of units, the } \\
\text { middle tubes' efficiency could be } \\
\text { reduced } \\
\text { - Causes local area fogging }\end{array}$ \\
\hline
\end{tabular}

\subsubsection{CNG utilisation}

CNG will be either used as fuel for vehicles, or depressurized for industrial or private consumption.

When depressurising, special attention must be given to the gas temperature as it could drop by up to $40^{\circ} \mathrm{C}$ during expansion (refer to section 5.3.2).

\subsection{Safety}

\subsubsection{General}

The gas industry has always promoted and maintained a high level of safety in order to reduce the risk of incidents and to allow better integration with the environment.

This policy has allowed the gas industry to maintain a good accident record, and to limit the impact where accidents have occurred. This low record of accidents is the result of compliance with strict rules and procedures by the gas industry, users and regulators.

The main safety principles adhered to, regardless of plant size and function are:

- Prevention (using passive protection ${ }^{3}$ and strict procedures)

- Monitoring (leak and fire detection among others)

- Mitigation (active protection)

\subsubsection{LNG}

Since its first deployment in the 1960's, the LNG industry has implemented ever stricter rules to minimize the incidence of accidents, and reduce the impact severity when accidents do occur.

\footnotetext{
${ }^{3}$ Such as safety spacing, fire and embrittlement protection, specific electrical material for hazardous areas
} 
These rules are defined by standardization committees, the most important of which are NFPA (NFPA 59A ${ }^{4}$ ) and EN (EN 14735). From design through construction to operation, specific conditions and constraints are imposed and strictly applied.

Since the emergence of the mini and micro LNG chains, mainly being used for fuelling and more recently ship bunkering, new rules are being set up that take account of the size and the operating conditions of these types of facility. It should be noted that the standardization committees are often following and reacting to market developments rather than leading the way.

\subsubsection{CNG}

Transporting large quantities of gas under high pressure (100 up to 250 barg) raises three major safety issues:

- Integrity of the containment system: the stored energy of compressed gas is very high and can reach the equivalent of hundreds of mega joules (MJ). The escaping highly pressurised gas could propel flying fragments over a long distance.

- Integrity of the carrier's hull: the tremendous weight of the containment system results in the transference of high loads from the CNG containment system to the ship's structure. The containment system must also be able to sustain loads from the ship in difficult sea conditions, or truck movement in collisions.

- Risk of explosion: The nature of the containment system, which often consists in sideby-side assemblies of cylinders, may create a confined space in the ship's hold in which a gas leakage (from the cylinders, but more likely from the manifolds) may create an explosive atmosphere. (N.B. DNV's rules require the hold space to be inerted with nitrogen or with other suitable non-corrosive, non-flammable medium).

The CNG industry complies with the general rules for the transport etc of gas, with specific standards for fuelling stations. The CNG chain is, up to now, not covered by specific industrial standards giving some freedom to the designers of the chain, within the limits of the chain component requirements.

\subsection{Technical comparison of the elements in LNG \& CNG chains}

The technical comparison of the elements in LNG and CNG chains is summarised in the following table.

\footnotetext{
${ }^{4}$ NFPA 59 A: Standard for the Production, Storage, and Handling of Liquefied Natural Gas (LNG)

${ }^{5}$ EN 1473: Installation and equipment for liquefied natural gas - Design of onshore installations
} 


\begin{tabular}{|c|c|c|c|}
\hline Parameters & LNG & CNG & $\begin{array}{l}\text { Advantage for } \\
\text { LNG or CNG }\end{array}$ \\
\hline Operation & $\begin{array}{l}\text { Shuttle oriented with } \\
\text { buffer storage }\end{array}$ & $\begin{array}{l}\text { Constant flow through } \\
\text { the chain }\end{array}$ & $\begin{array}{l}\text { To be checked on a } \\
\text { case by case }\end{array}$ \\
\hline Gas processing & $\begin{array}{l}\text { Several technologies } \\
\text { covering all required } \\
\text { capacities }\end{array}$ & $\begin{array}{l}\text { Mainly just gas } \\
\text { compression but } \\
\text { parameter control } \\
\text { during operation is a } \\
\text { key issue }\end{array}$ & $\mathrm{CNG}$ \\
\hline Loading/unloading & $\begin{array}{l}\text { Conventional arms or } \\
\text { cryogenic hoses }\end{array}$ & $\begin{array}{l}\text { High pressure hoses } \\
\text { with risk of explosive } \\
\text { gas release }\end{array}$ & LNG \\
\hline $\begin{array}{l}\text { Storage in large } \\
\text { capacities }\end{array}$ & Proven technologies & $\begin{array}{l}\text { More sophisticated } \\
\text { technologies not yet } \\
\text { proven }\end{array}$ & LNG \\
\hline \multirow[t]{3}{*}{ Transportation } & $\begin{array}{l}\text { Low pressure and } \\
\text { larger capacities for a } \\
\text { given containment } \\
\text { volume }\end{array}$ & $\begin{array}{l}\text { High pressure and } \\
\text { smaller capacities for a } \\
\text { given containment } \\
\text { volume }\end{array}$ & LNG \\
\hline & $\begin{array}{l}\text { Special cryogenic } \\
\text { materials required }\end{array}$ & $\begin{array}{l}\text { No special materials } \\
\text { required }\end{array}$ & $\mathrm{CNG}$ \\
\hline & $\begin{array}{l}\text { Fewer trucks needed } \\
\text { for given gas volume }\end{array}$ & $\begin{array}{l}\text { Larger number of trucks } \\
\text { needed for given gas } \\
\text { volume limits CNG to } \\
\text { small gas volumes }\end{array}$ & LNG \\
\hline Utilisation & $\begin{array}{l}\text { Extensive experience } \\
\text { even though scale } \\
\text { being considered is } \\
\text { smaller }\end{array}$ & $\begin{array}{l}\text { Experienced for smaller } \\
\text { capacities }\end{array}$ & $\begin{array}{l}\text { Both have pros and } \\
\text { cons }\end{array}$ \\
\hline Flexibility & $\begin{array}{l}\text { LNG and/or gas and } \\
\text { CNG distribution }\end{array}$ & $\begin{array}{l}\mathrm{CNG} \text { and/or gas } \\
\text { distribution }\end{array}$ & LNG \\
\hline Safety & Good safety record & $\begin{array}{l}\text { Risk of explosion due to } \\
\text { high pressure } \\
\text { No experience with } \\
\text { high capacity } \\
\text { transportation }\end{array}$ & LNG \\
\hline
\end{tabular}

Table 8: LNG / CNG comparison

\subsection{Suitability for associated gas recovery}

The technologies are available, with different levels of maturity from the experience gained to date and for different transportation conditions (quantities, distances), for the implementation of both LNG and CNG chains. 
The technologies allow a choice of implementation options to suit the volume of associated gas to be transported and the distance from field to consumer.

Gas pre-treatment to condition the gas is a well-known process in the gas industry and is not an obstacle to implementation of either LNG or CNG chains.

\section{6. $\quad$ COSTS}

\subsection{General}

For cost comparison, the main parameter is the cost of delivered energy (MMBTU).

The cost of the delivered energy is the sum of the costs for:

- The gas purchased from the producer (recovered from the field flared gas)

- The gas pre-treatment (refer to section 6.2)

- The gas processing (either liquefaction or compression)

- The gas transportation (either by ship or on road)

- The gas delivery to consumers

These individual costs are all directly impacted by local conditions, regulations and gas characteristics.

As costs are very dependent on specific conditions, only orders of magnitude can be provided in the following summary.

Moreover, the cost analysis comparison is covering high CAPEX and lower OPEX on the LNG side, whilst low CAPEX and higher OPEX on the CNG side. Typically these higher CAPEX in the LNG chain should be balanced against higher CNG chain operating costs (especially transportation), and the higher transported energy density in the case of LNG. A full life cycle cost analysis should thus be applied. As the experience and data are too limited or, even, not existing in the case of $\mathrm{CNG}$, the comparison is using all-inclusive rates estimated in literature and previous studies.

\subsection{Gas treatment costs}

The gas treatment costs for both LNG and CNG pre-processing can be estimated from following graph: 


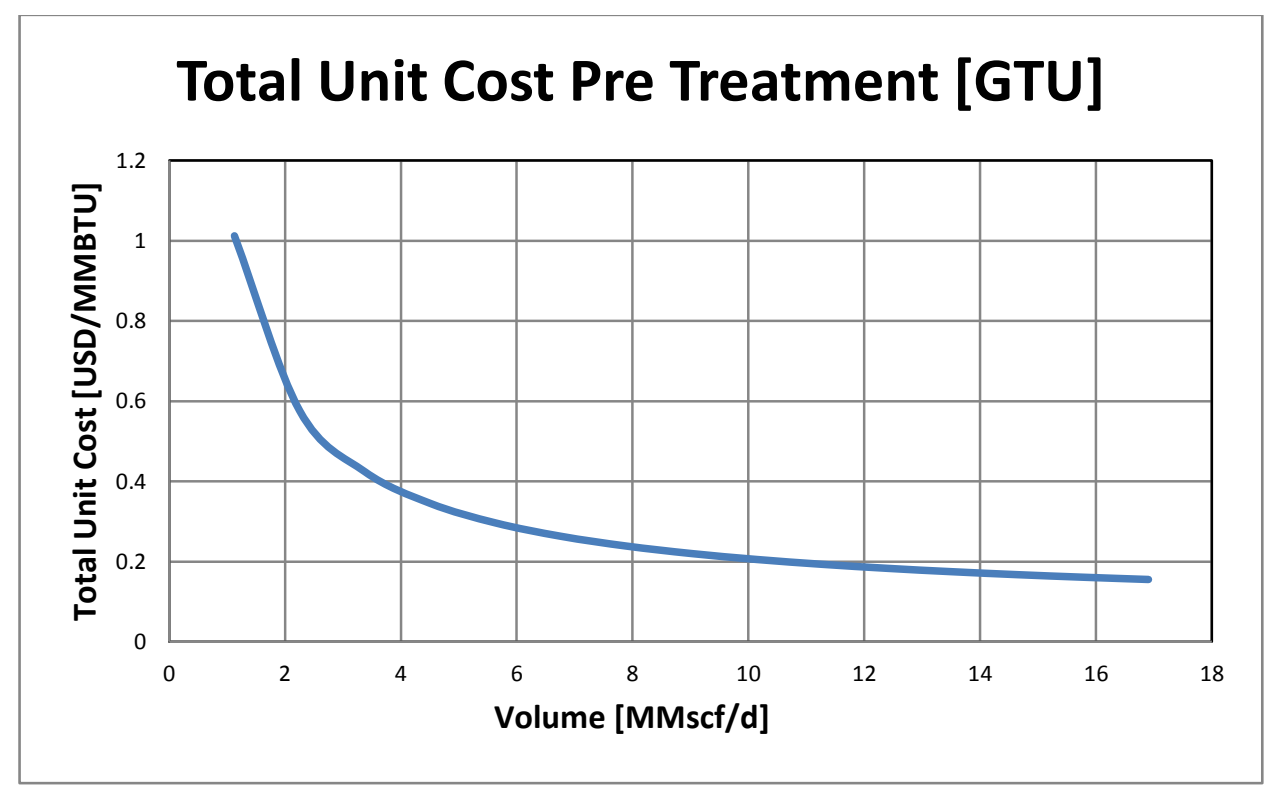

Figure 34: Gas treatment Unit cost

Cost of associated gas treatment as a function of daily volume of gas production

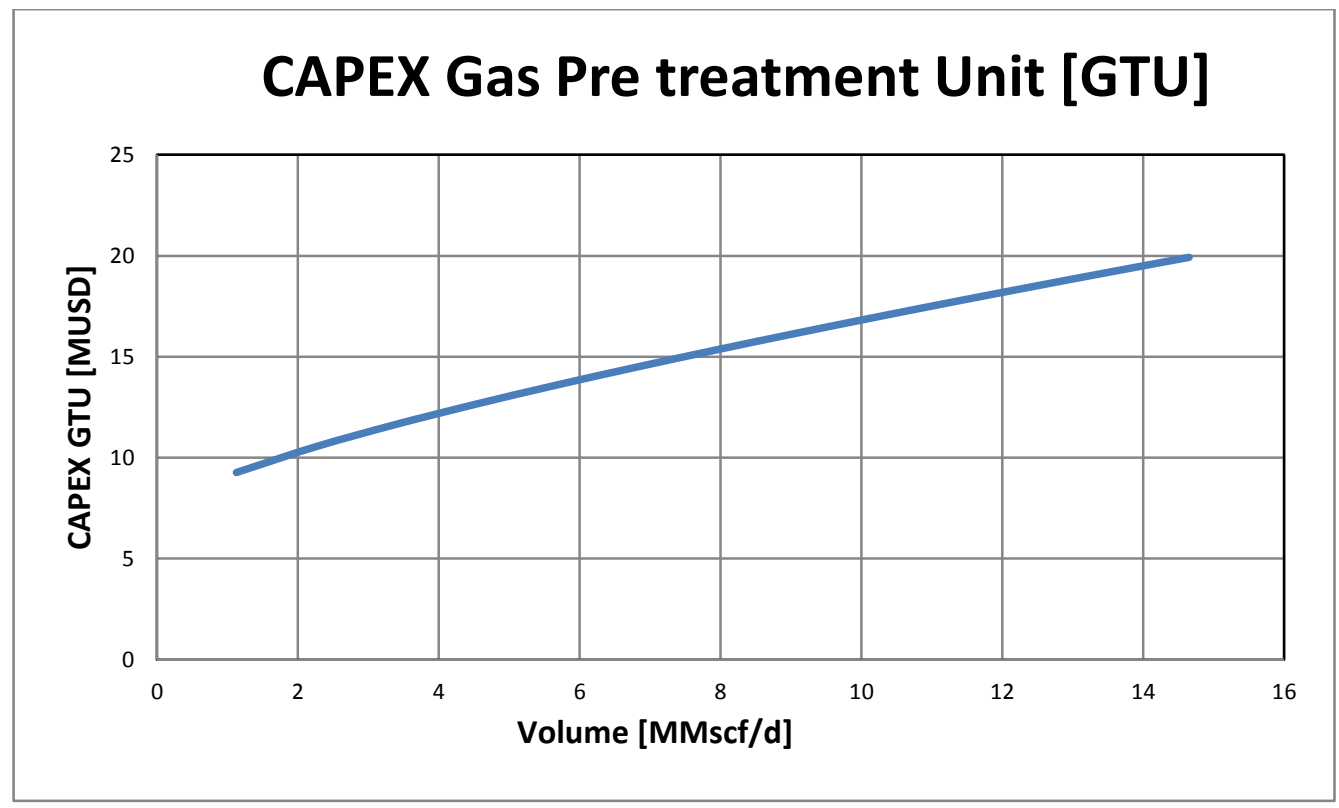

Figure 35 Capital Expenditure of the gas treatment

Capital Expenditure of the gas treatment as function of daily volume of production

\subsection{LNG chain costs}

The order of magnitude unit LNG chain costs per MMBTU are a function of a number of parameters, the most important of which is gas volume. 
- Gas liquefaction ${ }^{6}$ :

- LNG transportation8:

- Marine:

- Road:

- Gas delivery

- LNG:

- Gas:
3.0 - 5.0 USD/MMBTU

\section{5 - 3.0 USD/MMBTU}

1.0 - 2. USD/MMBTU

$0.2 \mathrm{USD} / \mathrm{MMBTU}$

0.5 - 1.5 USD/MMBTU

LNG in liquid form could therefore be delivered to a customer at a cost around 5.5USD/MMBTU for $15 \mathrm{MMscf} / \mathrm{d}$, while at around $8 \mathrm{USD} / \mathrm{MMBTU}$ for $1 \mathrm{MMscf} / \mathrm{d}$., excluding the gas molecule cost and including gas treatment.

The re-gasified gas could be delivered for a cost around 6 USD/MMBTU for $15 \mathrm{MMscf} / \mathrm{d}$ whilst around 9.5 USD/MMBTU for $1 \mathrm{MMscf} / \mathrm{d}$, excluding the gas molecule cost and including gas treatment.

Generally the unit cost of the liquefaction process, transportation and delivery all increase as the plant size decreases. The above shown cost estimate figures are low cost/larger volumes, high cost/smaller volumes related.

\subsection{CNG chain costs}

\subsubsection{CNG transportation costs}

\subsubsection{GENERAL}

The main cost element in the CNG chain is transportation.

The available cost estimation are covering both gas compression and transportation.

\subsubsection{MARINE TRANSPORTATION}

For marine and river transportation, the CNG chain has not yet been fully developed and there are therefore no reliable cost benchmarks.

A number of marine technology suppliers have published some data (Sea NG, Votrans and Knutsen) and this has been used to estimate marine transportation costs.

\footnotetext{
${ }^{6}$ Gas liquefaction cost includes gas treatment and storage.

7 Higher is the capacity, lower is the cost per unit

8 Higher is the quantity of energy, lower is the transportation cost. However the distance will have an opposite impact
} 


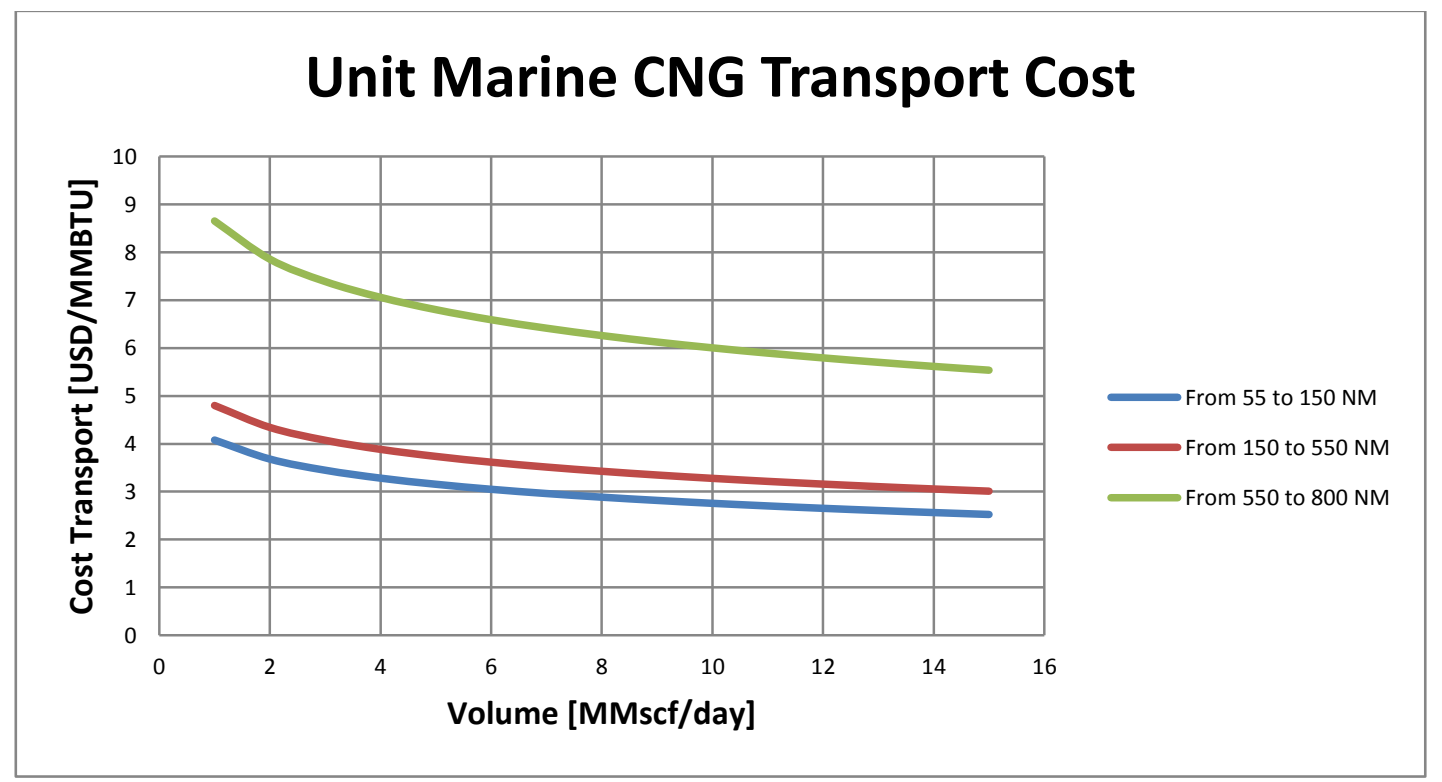

Figure 36: Marine CNG transportation costs

Cost of CNG transportation as function of daily volume production and distances (nautical miles)

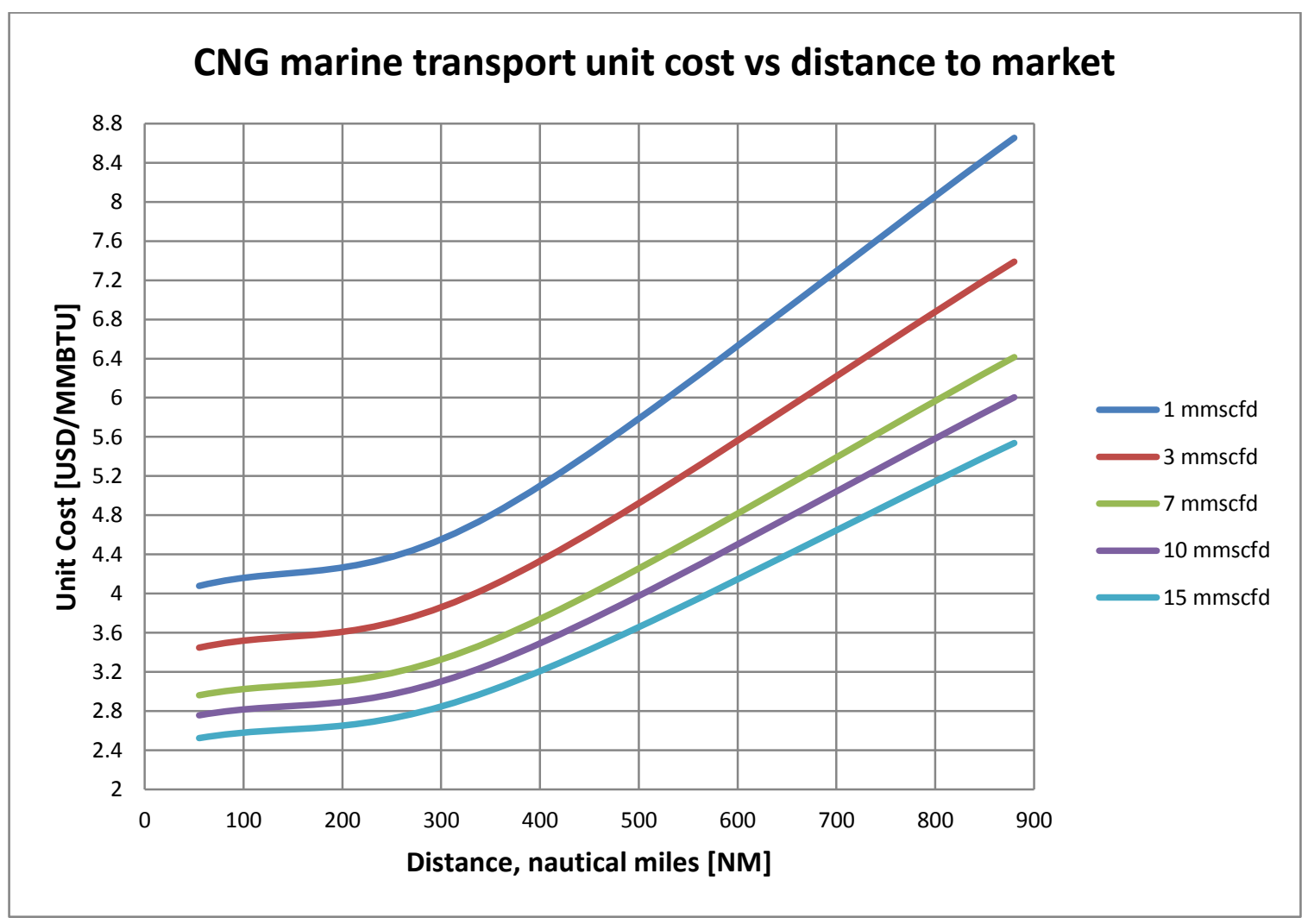

Figure 37: Marine CNG transportation costs vs distance to market

Each CNG chain supplier has its own view on the transportation viability and attractiveness of its CNG technology. These supplier opinions are noted as follows: 
- For CETech, in the range of between 18,000 and 100,000 MMscf on a sea journey of between on 300 and 2,000NaMi

- For VOTRANS, in the range of between 54,000 and 255,000 MMscf on a sea journey of between 250 and $300 \mathrm{NaMi}$

- For Sea NG, in the range of between 20,000 and 120,000 MMscf on a sea journey of between 250 and 1,500 NaMi

- For Trans Canada-CNG, if less than 200,000 MMscf and on a sea journey of less than $500 \mathrm{NaMi}$

\subsubsection{LAND TRANSPORTATION}

For onshore $\mathrm{CNG}$ chain, for relatively low volumes of gas, it is economically viable to utilize high capacity $\mathrm{CNG}$ trailers to transport natural gas to areas without pipeline supply.

CNG transportation by truck pushes its limit when the volumes of associated gas to be exported exceed $5 \mathrm{MMscf} / \mathrm{d}$ due to the required loading facilities. In simple terms, contrary to the comment made about the sizes of CNG ships, the trucks are too small.

For volumes lower than $5 \mathrm{MMscf} / \mathrm{d}$, the total unit cost per MMBTU would range between 5.13 to 5.2 USD.

The CNG transportation costs are illustrated by following figures for the defined distance ranges

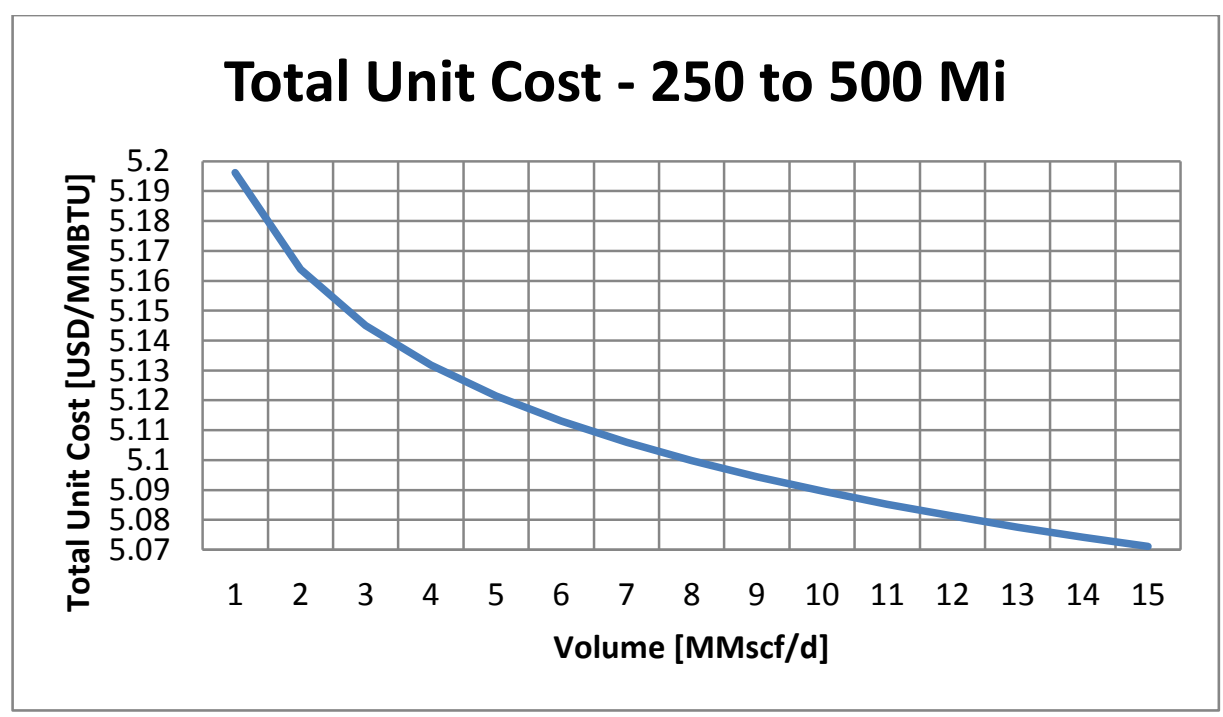

Figure 38: CNG transportation - Unit Prices for 250 to 500 miles 


\section{Total Unit Cost - 500 to $750 \mathrm{Mi}$}

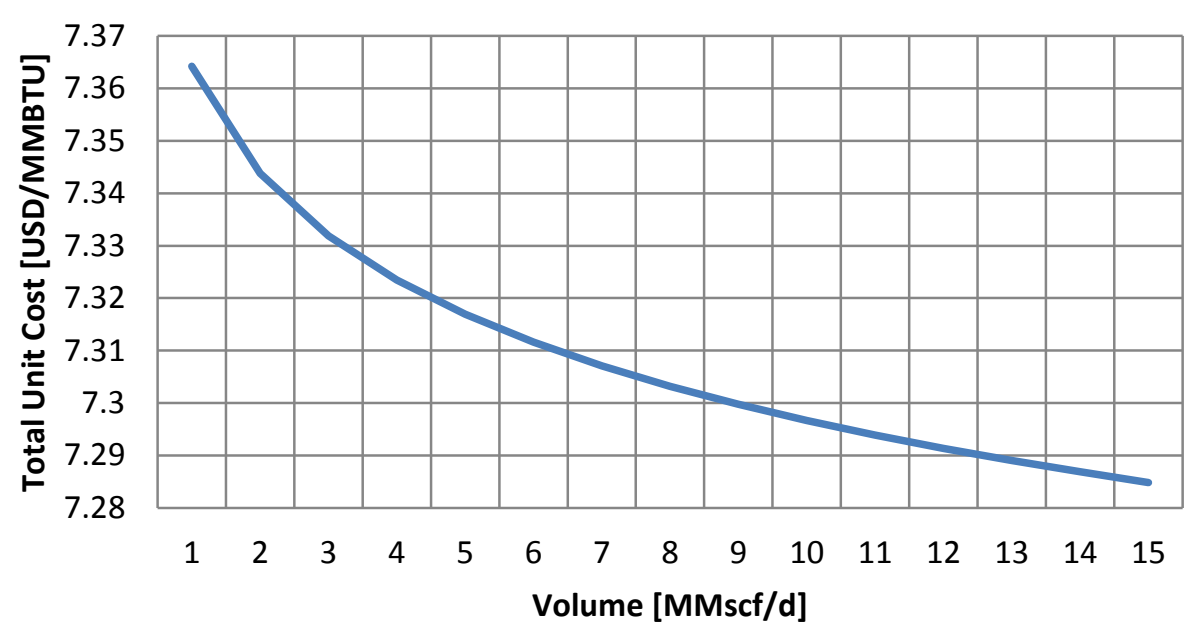

Figure 39: CNG transportation - Unit Prices for 500 to 750 miles

\section{Total Unit Cost - 750 to $1000 \mathrm{Mi}$}

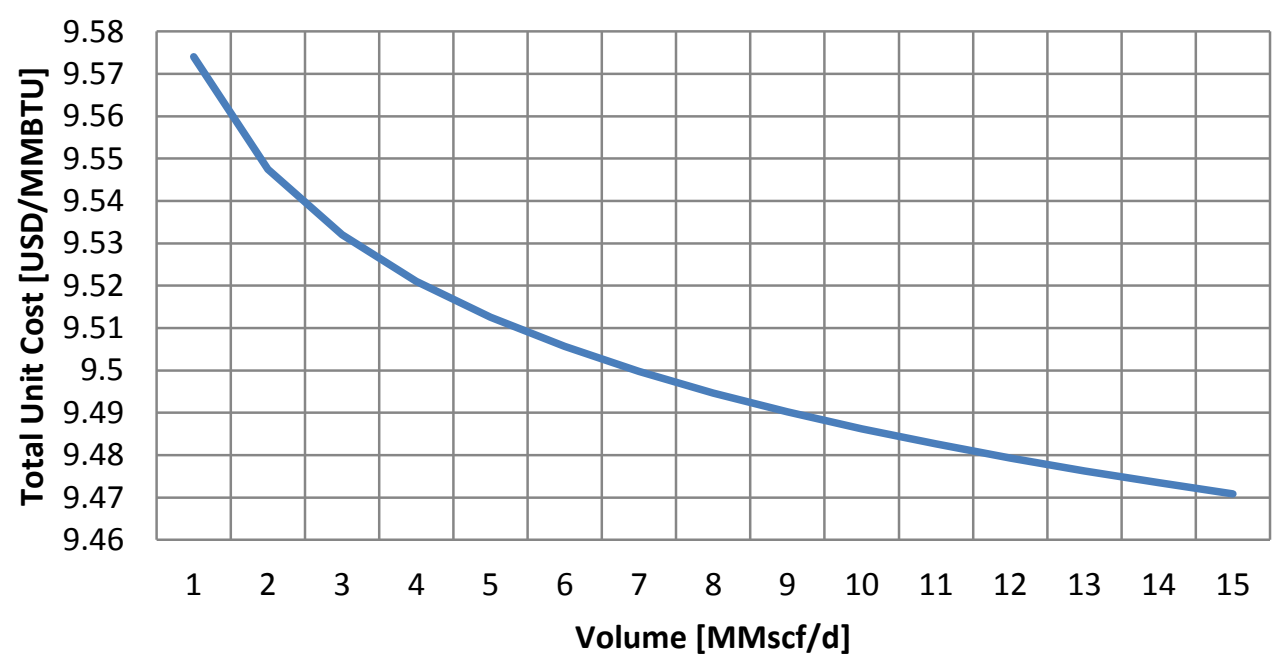

Figure 40: CNG transportation - Unit Prices for 750 to 1,000 miles 


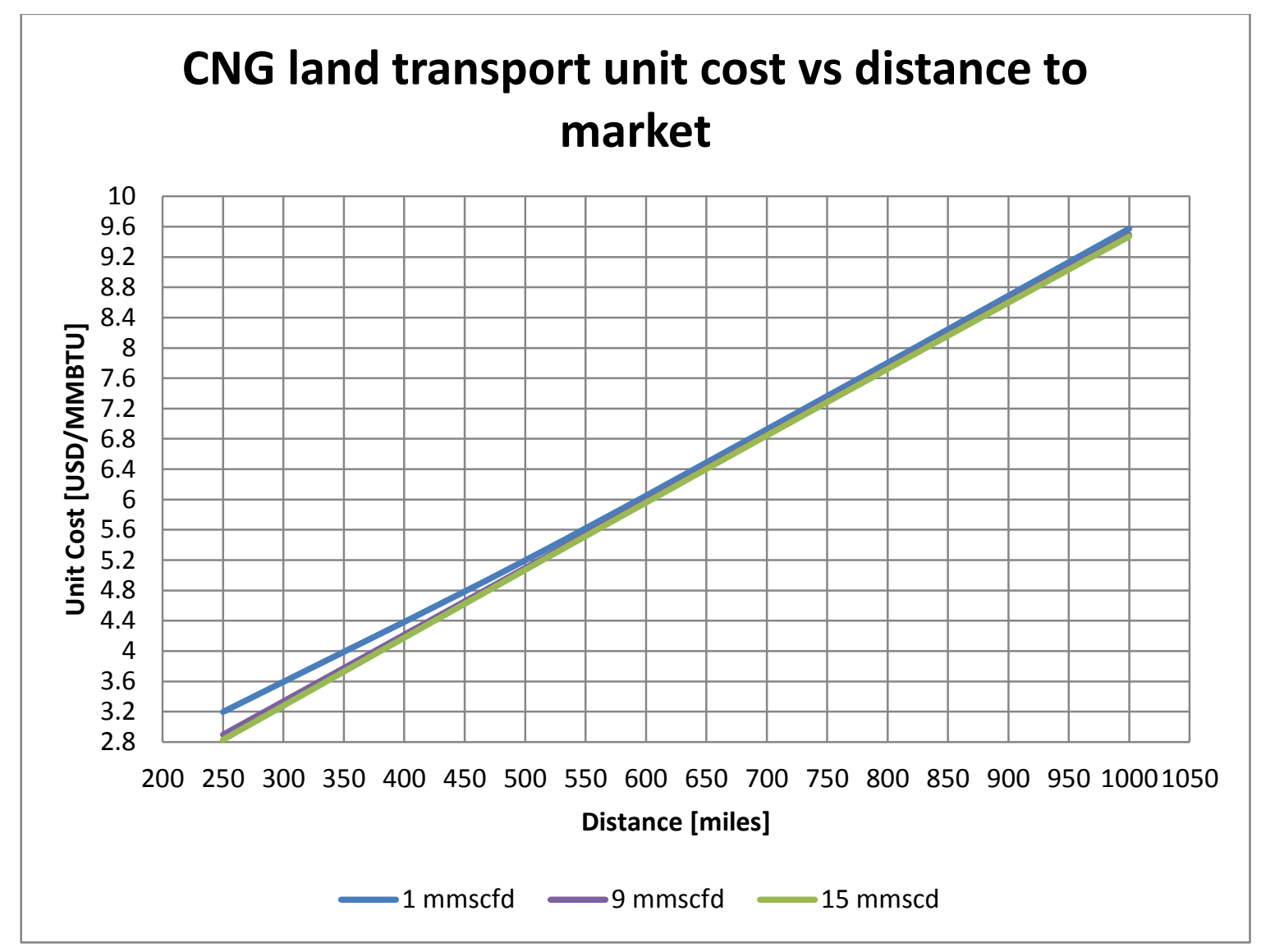

Figure 41: CNG land transport unit cost vs distance to market

\subsubsection{CNG price at delivery point}

The order of magnitude CNG chain costs (capital plus operating) per MMBTU are a function of a number of parameters, the most important of which is gas volume:

- Gas processing Is included in the transportation costs

- Gas transportation:

- UTILISATION

- Marine on short distances up to 1,000 km:

- Marine on longer distances:

- Road:

$5.2 \quad$ USD/MMBTU

- Gas delivery:

$0.2 \quad$ USD/MMBTU

CNG could therefore be delivered to a customer at a cost around 3-11 USD/MMBTU, excluding the gas molecule cost but including the gas treatment. 


\subsection{Cost examples}

The following tables will give cost estimates (capital plus operating) for defined capacities and marine or road distances:

- Examples of 3 and $10 \mathrm{MMscf} / \mathrm{d}$

- Examples of 150 and 800 nautical miles for marine transportation

- Examples of 250 and 1,000 miles for road transportation

\begin{tabular}{|c|c|c|c|c|c|}
\hline \multicolumn{6}{|c|}{ Long distance } \\
\hline \multirow{8}{*}{$\begin{array}{l}\frac{0}{0} \\
\frac{5}{5} \\
\frac{5}{4} \\
\frac{4}{0}\end{array}$} & \multicolumn{5}{|c|}{ All cost in USD $D_{2025} /$ MMBTU } \\
\hline & & \multicolumn{2}{|c|}{ Marlne - 3MM5CFD / 550-800 MN } & \multicolumn{2}{|c|}{ Marlne - 10MM5CFD / 550-800 MN } \\
\hline & Items & ING & CNG & LNG & ONG \\
\hline & Gos Treatment & 0.42 & 0.42 & 0.21 & 0.21 \\
\hline & Processing (liquefoction/Com pression) & 4.71 & 0.73 & 3.71 & 0.70 \\
\hline & Trans portation & 3.36 & 6.43 & 2.86 & 5.22 \\
\hline & Delivery & 1.56 & 0.5 & 1.06 & 0.5 \\
\hline & Total & 10.05 & 8.08 & 7.84 & 6.63 \\
\hline \multirow{8}{*}{ 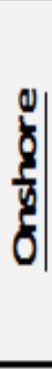 } & \multicolumn{5}{|c|}{ All cost in USD ${ }_{[2015} /$ MMBTU } \\
\hline & & \multicolumn{2}{|c|}{ Truck-3MM5CFD / 750-1000 Ml } & \multicolumn{2}{|c|}{ Truck - 10MM5CFD / 750-1000 Ml } \\
\hline & Items & LNG & CNG & LNG & CNG \\
\hline & Gos Treatment & 0.42 & 0.42 & 0.21 & 0.21 \\
\hline & Processing (liquefoction/Compression) & 4.71 & 0.73 & 3.71 & 0.70 \\
\hline & Trans portation & 4.93 & 8.81 & 4.68 & 8.79 \\
\hline & Delivery & 1.56 & 0.50 & 1.06 & 0.50 \\
\hline & Total & 11.62 & 10.46 & 9.66 & 10.20 \\
\hline \multicolumn{6}{|c|}{ Short Distance } \\
\hline \multirow{8}{*}{$\begin{array}{l}\frac{0}{0} \\
\frac{8}{\sqrt{3}} \\
\frac{4}{0}\end{array}$} & \multicolumn{5}{|c|}{ All cost in USD ${ }_{[2025]} /$ MMBTU } \\
\hline & & \multicolumn{2}{|c|}{ Marlne-3MMSCFD / 55-150 MN } & \multicolumn{2}{|c|}{ Marlne - 10MM5CFD / 55-150 MN } \\
\hline & items & ING & CNG & LNG & ONG \\
\hline & Gos Treatment & 0.42 & 0.42 & 0.21 & 0.21 \\
\hline & Processing (liquefoction/Com pression) & 4.71 & 0.73 & 3.71 & 0.70 \\
\hline & Trans portation & 2.36 & 3.00 & 1.86 & 2.40 \\
\hline & Delivery & 1.56 & 0.5 & 1.06 & 0.5 \\
\hline & Total & 9.05 & 4.65 & 6.84 & 3.81 \\
\hline \multirow{8}{*}{ 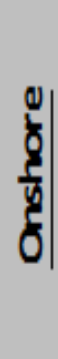 } & \multicolumn{5}{|c|}{ All cost in USD $D_{(2025} /$ MMBTU } \\
\hline & & \multicolumn{2}{|c|}{ Truck-3MMSCFD / 0-250 Ml } & \multicolumn{2}{|c|}{ Truck-10MM5CFD / 0-250 Ml } \\
\hline & Items & LNG & CNG & LNG & CNG \\
\hline & Gas Treatment & 0.42 & 0.42 & 0.21 & 0.21 \\
\hline & Processing (liquefoction/Com pression) & 4.71 & 0.73 & 3.71 & 0.70 \\
\hline & $\begin{array}{lc}\text { Trans portation } \\
\end{array}$ & 1.43 & 2.20 & 1.18 & 2.20 \\
\hline & Delivery & 1.56 & 0.50 & 1.06 & 0.50 \\
\hline & Total & 8.12 & 3.85 & 6.16 & 3.61 \\
\hline
\end{tabular}




\section{POTENTIAL FOR DEVELOPMENT}

\subsection{General}

The gas market is developing and gaining flexibility through its increasing diversification. This diversification is illustrated in the following figure 34 for a LNG chain and that could be extended to the CNG chain.

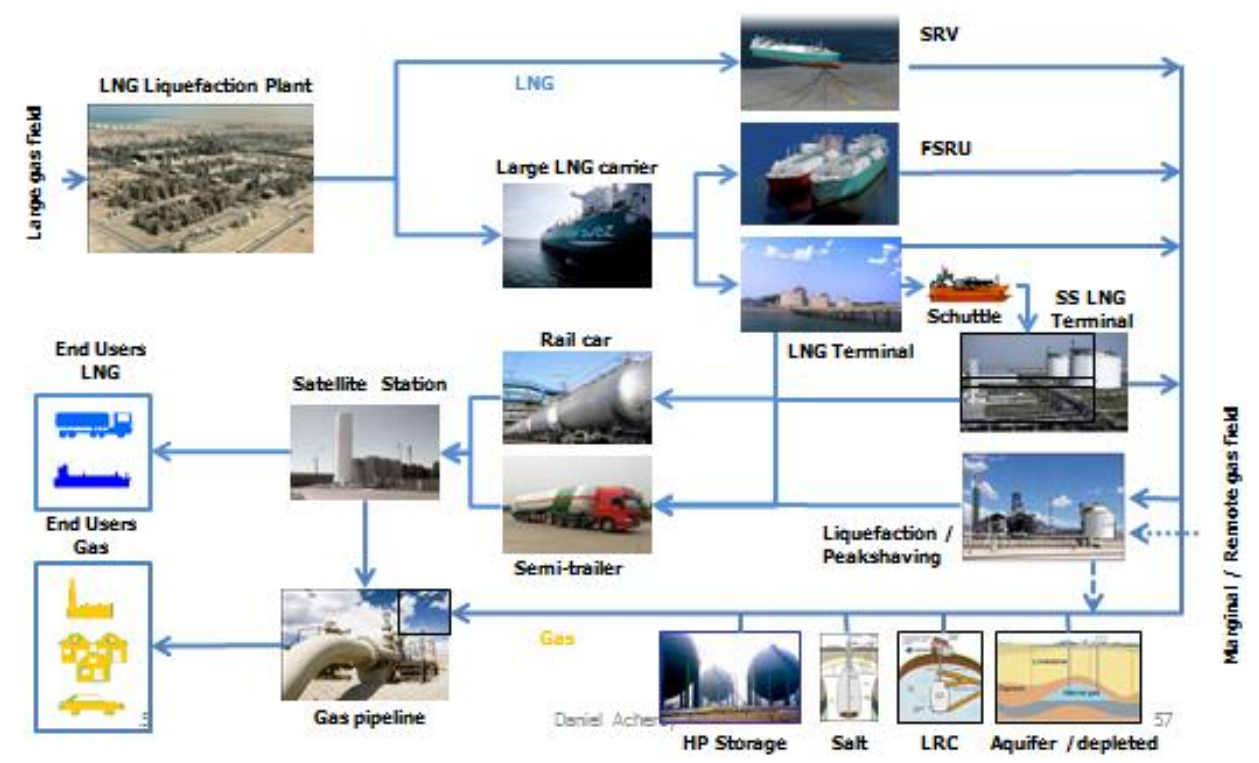

Figure 42: NG Chain

In this example of a potential gas market, $\mathrm{CNG}$ can complement the LNG to develop the business and bring gas to a wide range of potential consumers. At any point in the gas chain, CNG stations could be installed to bring gas to isolated small consumers or to CNG fuelling stations.

\subsection{Experience}

\subsubsection{USA}

Since the mid-1950s, in the USA the domestic consumption of energy has exceeded domestic production. The gap increased over time, reaching a maximum in 2005.

Since then, new technologies and that emergence of shale gas has allowed a rapid increase in gas and oil production, and the USA has become the largest global oil and gas producer.

Historically, natural gas imports to the USA were mainly through pipelines from Canada and Mexico. The LNG was then used to "peak shave" the supply/demands. Sixty eight peak-shaving plants were built across the USA to liquefy the excess of imported gas during the summer period, and to re-inject the stored gas back into the grid during the winter season when demand exceeded the available supplies. 
Since the 1970s, the USA has imported LNG via re-gasification plants to supplement the pipeline gas imports, but during the last few years indigenous production has exceeded demand and the USA is now turning to LNG export (foreseen by 2017).

The USA initiated the use of LNG as fuel for heavy-duty vehicles. The 1992 Energy Policy Act, which sought to increase clean energy use and to improve overall energy efficiency, marked the first governmental incentive for traditional fuelled vehicle users to switch to alternative fuelled vehicles. Specific liquefaction plants were built in 1994 and 14 such plants are currently exclusively dedicated to the production of LNG for fueling.

There are 63 public LNG dispensing stations through USA whilst 38 private stations serve only own fleet. As such, LNG vehicles currently in operation are limited in range by the distribution/availability of stations. However as the infrastructure continues to quickly develop, broader opportunities for the LNG vehicle market will emerge.

Several projects have come on line since 2006 to promote the LNG use as fuel (Prometheus, Bakken, Shell, North Dakota LNG LLC, etc).

Recently, the USA initiated LNG delivery to islands (Hawaii and Caribbean) by ISOcontainers (40 feet long, about 20 t of LNG) taking the benefit of Ro-Ro logistic experience.

In parallel since the early 1990s, CNG fueling infrastructure experienced a rapid development in the USA. Further to the Energy Policy Act, in 1995, the Natural Gas Vehicle (NGV) Industry Strategy, issued by the National Gas Vehicle Coalition, Gas Research Institute and American Gas Association, was developed to set a unified vision of the market industry and to boost the use of natural gas in transportation.

As part of the industry approach, local NG distribution companies, which also became involved in marketing to secure a bigger share in the marketplace, got closer to the main manufacturing associations in order to promote more evolved NGV equipment.

While CNG has remained cheaper than diesel or gasoline, until recently the gap between them was not sufficient to justify the investment of vehicle conversion.

NGV supply infrastructure expanded until 1997, then reflecting the preference for flexfuelled ethanol vehicles, declined to a low of 721 stations in 2007. Investments then began to increase again, at a moderate pace until 2011 (47 new stations per year on average), then more aggressively (177 new stations per year on average). This recent expansion (2008-2014) is explained by the gas availability from unconventional fields and a severe excise duty increase on ethanol in 2011.

CNG and LNG uses would not have a significant impact in the flaring reduction in USA. The Commission estimated only $0.1 \%$ of the current flared gas in the field could be reduced by these technologies. However, several experiences addressed to diminish flaring have been raised.

\subsubsection{China}

This section offers a review of the uses and main drivers of mini/micro LNG liquefaction and CNG in China, focusing on those suitable to small volumes (1-15 MMscf/d) of associated gas.

A series of factors sustain the growth of the small gas industry. 
First of all, the demand-supply gas balance in China is very tight, while the pipeline grid is limited. Since China's natural gas pipeline infrastructure density is only $30 \%$ compared to developed countries such as the US, most communities lie outside the reach of pipelines, making LNG/CNG storage and trailers necessary to transport gas to those regions.

In eastern and southern China, many industrial and urban users ${ }^{9}$ still have a limited supply of natural gas, especially for peak-shaving purposes during winter. However, gas use in those areas is likely to increase, boosted by the expansion of urban gas distribution networks, and tightening even more daily and seasonal peaks supply in the coming years. Therefore, it is very important to develop LNG storage capacity.

Secondly, in regions far from the main transmission pipeline, where it is not economically viable to build pipeline connections, mini-LNG could be a viable alternative solution for gas supply. In addition, natural gas serves as an alternative fuel in the transport sector. Finally, from the producer's perspective, $\mathrm{LNG}$ is also a solution to unlock the potential of stranded gas fields.

Over these geographical constraints, China's concerns about environmental issues and securing energy requirements in the future have triggered an official policy to pursue a rapid rise in natural gas use. The 2010 five-year development plan called to boost to $8 \%$ the share of natural gas in the total primary energy matrix by 2015 (from 5\% in 2011).

At the end of the 1980s, the first CNG filling stations came online in China, specially addressed to serve taxis and light commercial vehicles. But the most populous country in the world made a significant deployment of CNG five years ago, when cities, such as Beijing, Chengdu and Hong Kong, converted buses and taxis to CNG technology in an effort to reduce notorious toxic urban air pollution. Currently, it is estimated that there are almost 3 million NGV fuelled vehicles on the road, six times as many as just five years ago, when deployment of NGVs took off.

In meantime the national government has strongly encouraged the deployment of natural gas fueling infrastructure, especially for LNG stations. In 2013, there were 3,350 CNG stations, and more notably, 1,844 LNG stations. The $12^{\text {th }}$ Five Year Plan (2011-2015) includes a target of 5,000 LNG stations.

The gas deployment is led by the three major Chinese oil and gas state-owned enterprises: China National Petroleum Corporation (CNPC, which do business as PetroChina and via its subsidiary Kunlun Energy), China Petroleum and Chemical Corporation (Sinopec), and China National Offshore Oil Corporation (CNOOC). Some private energy companies, such as ENN Energy Holdings, Xinjiang Guanghui Industry Investment Group, and Hanas New Energy Group based in Ningxia and Shandong, are also doing business in the area.

China is also beginning to pay attention to the development of LNG as a vessel fuel, which should achieve coastal and inland shipping "green environmental protection". Vessel power changing to LNG would become the development trend.

${ }^{9}$ Urban users are: residential, commercial and transportation. 
Currently, the main experience carried out in China is "changing diesel to LNG" for vessel fuel. In 2009, usage of vessel power for the diesel-LNG hybrid technology project in Suqian City, Jiangsu Province was officially launched. In 2010, "Su-Su goods 1260" freighter in the Northern section of the Grand Canal began real ship trials. Afterwards, a hybrid diesel-LNG ship, carrying 3,000 tons of sand, sailed from Suqian City into Huai'an City. Currently, some Chinese companies, such as Hubei Xilan, Beijing Youlu, Guilin Xin'ao, Xinjiang Guanghui, Fujian Zhongmin, are in the process of changing some vessels of their fleet from oil to gas.

\subsubsection{Pakistan}

In the 1990s, Pakistan started promoting the use of CNG as fuel for vehicles as an alternative to gasoline. Over the following 20 years, the CNG market increased rapidly making Pakistan the second largest country in CNG vehicles fleet in the World, only after Iran, with approximately 2.8 million vehicles. According to the Natural and Bio Gas Vehicle Association (NGVA), $80 \%$ of the Pakistani cars are currently running with CNG.

The energy crisis the country is suffering includes natural gas shortages (due to gas reserves decrease) which are affecting some key sectors of the Pakistani economy such as power generation and industry (fertilizers, cement, textile, etc.). Due to this the Pakistan government has introduced some restrictions in natural gas consumption.

Pakistan is currently looking at several alternatives to solve natural gas shortage such as to import LNG. There are two LNG projects underway: Floating Regasification and Storage Unit (FSRU) at Port Qasim which is due to be commissioned in Q2, 2015 and a second FSRU near Karachi which is at the study stage.

With the arrival of LNG in the country, the Pakistan government expects to reduce the petrol consumption by almost two billion litres per annum and recover the industry and CNG as fuel which has suffered from natural gas restrictions over the last 4 years.

\subsubsection{Other experiences}

Besides the analyzed experiences, there are other countries which have been developing interesting and successful projects with CNG technology. Some of these practices should be taken into account in future CNG developments in order to capitalize on the already acquired knowledge related to the field. In this regard, a study of Yeh (2007) has underlined the following policies ${ }^{10}$ :

- demand side market creation programs: mandatory conversion of government fleets and urban buses procurement,

- supply side market creation programs: governmental investments in refueling stations, pipelines and conversion kits,

- financial incentive programs offered to consumers and equipment suppliers: subsidies and tax breaks to reduce prices of natural gas specifically for transportation, rebates and loans to lower or eliminate consumers' vehicle conversion costs, exemptions from import duties and the lowering or elimination of import tariffs on machinery, equipment, and kits, and exemption from sales taxes for the construction and operation of refueling stations, 
- regulation-based policy: industry standards, regulations, and certification programs; liberal licensing for CNG retailing; expedited approvals for the installation of CNG refueling stations; forced early retirement of old fleet vehicles, city buses, and taxis; penalties for operating city buses on "dirty" fuels such as diesel; and traffic restrictions for which NGVs are exempt,

- information - or coalition - type policies: government/industry/non-governmental organization (NGO) coalitions and government-funded research and development programs,

- interactions between stakeholder groups, such as incentives provided by equipment suppliers to consumers: the voucher scheme developed in New Zealand.

\subsection{Lessons from analyzed experiences}

Based on the described experiences in USA, China and Pakistan, several lessons on the development of small volumes of gas, either LNG or CNG, can be learned.

First of all, the technology is available. More mature for high quantity transportation in the LNG side and more developed for vehicle fuel on the CNG side.

Secondly, small scale solutions for gas transportation have been more developed, using mainly LNG chain, when the following conditions exist:

- Restrictions in infrastructure:

- In the USA, peak shaving was used to solve pipeline network restrictions or deficient storage capacity.

- In China, domestic gas demand had a boom which could not be matched by the required infrastructure development (gas transportation and transmission). LNG virtual chain provided a transitional solution to solve the gap.

- Demand does not reach the minimum volume required to invest in traditional gas infrastructure transportation (mainly for isolated areas).

Thirdly, more competitive natural gas prices in the transportation sector against other hydrocarbon fuels. This natural price attractiveness is brought by strategic public policies through laws to reduce emissions or through incentives by differential taxation.

However, several barriers for the development of the gas chain, either LNG or CNG have been found, such as: the "coordination problem" for investment decisions (for infrastructure development and the consumer market availability), the minimum scale (demand / supply) required to assure economic viability and the prices that the demand is willing to pay for the new facilities.

Considering the experiences of the USA and China on ways to economically seize small LNG volumes and the main identified drivers, the lessons learned could help to outline some recommendations towards the development of this kind of market in less developed economies with smaller infrastructure, such as Nigeria, Iraq and Indonesia. 
It is important to notice there is a main difference between the USA and China cases that could be considered as a basic lesson regarding the implementation in less developed countries. In China, small scale LNG developments are mostly supported and carried out by State-owned companies as part of a National development policy. On the contrary, in the USA, development seems to be linked to decentralized market decisions (although peak shaving operations are framed in a regulatory scheme). Each alternative implies significant challenges and risks, especially in low and middle income economies.

However, experiences from China and the USA were directed to supply residential, industrial and transport demand. Two characteristics of this technology worth highlighting are the "fast-track" implementation and the relatively reduced investment (compared to pipelines or large scale facilities), making possible the rapid settlement of industries with high positive impact on a country's economic growth.

For example, small LNG chains may enable the installation of fertilizer companies, boosting the food industry, or the installation / expansion of construction industry, a very dynamic sector of the economy of any country. Small scale LNG can replace other fuels, like LPG, in industries looking for clean combustion (food industry) or heat control (ceramic industry).

Regarding the transportation sector, the experiences in China and the USA show natural gas as a competitive fuel against diesel and gasoline. The LNG, presenting less volume than $\mathrm{CNG}$, is recommended in large vehicles, running long distance and, therefore, needing longer range. Giving the size of these countries' economies and the extension of their lands and routes, this kind of vehicle is a growing trend.

In the market-type solution, a first issue to deal with is the coordination problem, frequently posed by economists at a theoretical level: the development of an efficient and sustainable scale means supply ${ }^{11}$ and demand ${ }^{12}$ decisions should be almost simultaneously taken. The problem is when no one is willing to make the first move. In China's case, the coordination problem is "solved" by the State, who acts as a "market-maker" enabling the existence of demand and/or supply until the industry reaches a sustainable scale.

Regardless of environmental benefits and even lower operative costs in some cases, the differential in cost of capital to be afforded by the introduction of the new technology is another arising problem. As in any LNG development - no matter what the scale -, investment represents an important share on LNG final price. Every asset is fully committed to the project and loses its value if any link of the chain breaks. For example, an LNG-fueled truck would lose practically its total resale value, when its purchase cost would have been $40 \%$ higher. Once more, in China's case the Government is able to finance and assume risks, becoming effective in developing the market - regardless of the efficient or inefficient use of public resources -. Considering the Chinese economy and its high demand of energy required for growth and development, LNG projects proved to be the right bet.

However, state-based market creation solutions do not always take into account the frequently diminished institutional capabilities present in developing countries, usually represented in the failure - or at least ineffectiveness - in the development and implementation of public policies, in this particular case, energy policies.

\footnotetext{
11 Liquefaction plants, storage facilities, fuel stations, fuel tanker trucks, etc.

12 Purchase of CNG-fuelled trucks, gas-fuelled ships, investments in conversion technologies, settlement of power generation facilities, etc.
} 
Furthermore, some experiences show that Foreign Direct Investment, usually performed by private companies, represents a way of transferring know-how, technology and financing for the implementation of a policy that the developing country could hardly achieve $^{13}$. At the same time, some economists have argued that FDI contributes to economic growth only when a sufficient absorptive capability of the advanced technologies is available in the host economy ${ }^{14}$.

\section{CONCLUSIONS}

\subsection{Findings}

From the comparison it appears that:

1. The gas treatment is similar for both options even if CNG actually requires slightly less treatment

2. The liquefaction is more complex than the $\mathrm{CNG}$ compression and requires more capital investment

3. CNG is perceived as being of a higher safety risk, due to the high operating pressure, in the range of $150-250$ barg

4. The volumetric efficiency (reduction of the gas volume at atmospheric conditions) is 150 to $300: 1$ for CNG, compared to LNG at approximately 600:1

5. CNG is considered to be less suitable for larger gas volumes and longer distances due to the large CNG transportation requirement (ships, barges or trucks) resulting from its lower volumetric efficiency; even with the best CNG container option, CNG requires at least twice the LNG chain transportation fleet for the same gas volume. The large scale of the CNG loading facilities also required for large gas volumes reinforces this conclusion. It is recommended that $\mathrm{CNG}$ should be limited to $5 \mathrm{MMscf} / \mathrm{d}$ and to $800 \mathrm{~km}$ in the case of road transportation for cost and operational complexity reasons, whilst CNG marine transportation should be limited to less than 2,000 $\mathrm{Na} \mathrm{Mi}$ (refer to section 6.4.1)

6. The higher investment/capital costs in an LNG chain should be balanced by the higher CNG chain operating costs.

The estimated costs for delivered gas, excluding the gas molecule cost, are detailed in section 6 .

As a summary:

1. For the LNG chain

- LNG in liquid form could therefore be delivered to a customer at a cost (capital plus operating) of around 5.5USD/MMBTU for $15 \mathrm{MMscf} / \mathrm{d}$, while at around $8 \mathrm{USD} / \mathrm{MMBTU}$ for $1 \mathrm{MMscf} / \mathrm{d}$, excluding the gas purchase cost.

\footnotetext{
13 Saggi, K. (2002), "Trade, Foreign Direct Investment, and International Technology Transfer: A Survey" World Bank Research Observer (2002) Volume 17, Issue 2, 191-235.

14 Borensztein, E., De Gregorio, J. \& Leec, J-W. (1998), "How does foreign direct investment affect economic growth?", Journal of International Economic, Volume 45, Issue 1, 1 June 1998, Pages 115-135.
} 
- Re-gasified LNG could be delivered for a cost (capital plus operating) of around $6 \mathrm{USD} / \mathrm{MMBTU}$ for $15 \mathrm{MMscf} / \mathrm{d}$ whilst around $9.5 \mathrm{USD} / \mathrm{MMBTU}$ for 1 MMscf/d, excluding the gas purchase cost.

2. For the CNG chain

- CNG could therefore be delivered to a customer at a cost (capital plus operating) of around $3-11$ USD/MMBTU, excluding the gas purchase cost.

\subsection{Conclusions}

The considered gas capacities, from 1 to $15 \mathrm{MMscf} / \mathrm{d}$, are suitable for delivery to small consumers, for industrial processes or mini power generation (up to $50 \mathrm{MW}$ ) or as fuel, either as CNG or as LNG.

The associated gas recovery will mainly depend upon the market demand and the attractiveness of the gas price versus other fuels.

The technology is available, at different levels and for different transportation conditions (quantities, distances) for the implementation of the both LNG and CNG chains.

Both options give opportunities to monetise the associated gas and to bring LNG or gas in remote areas or to specific markets.

The development of the chains will have to combine:

- the availability of the associated gas in marketable conditions

- the gas demands or as a minimum a potential for gas demand (conversion from other fuels)

- the attractiveness of the gas price, versus other fuels

It must be pointed out that Nigeria and Iraq show very important flaring levels (ranked second and third, respectively in the world's flaring ranking list), in absolute as well as relative terms related to their natural gas production. Indonesia, on the other hand, presents lower volume, but yet perfectly suitable for small-scale LNG projects. This feature, in addition to the country's insular geography, makes Indonesia's case - and the strategy to be defined for it - quite different from the other two countries.

However, uncertainty arises when trying to assess the existence of a critical mass to make LNG a viable fuel for large vehicles in countries such as Nigeria, Iraq and Indonesia. In these cases, CNG for vehicles (NGV) would have more chance for success as it is more suitable for light and mid-size vehicles, with more easily developed loading stations in urban areas.

Nevertheless, LNG could be part of a transport supply chain if, considering distance from gas fields and demand size, the technology results in the most convenient method to supply NGV stations.

Regarding LNG road transportation, conditions of road infrastructure and security must be considered, especially in Nigeria and Iraq. Difficult access or temporary floods, for example, result in higher supply costs because of stock shortage or redundant storage and transport infrastructure. 
In terms of security, LNG chains - like any other fuel - are vulnerable to piracy and terrorism, worsened by the fact of being a flammable fuel. But LNG is not a fungible asset i.e. it can only consumed in proper facilities; therefore it would have practically no resale value for illegal markets. Nevertheless, the validation of this assumption would need a deeper study on the subject.

Several projects could be economically viable in power generation, considering the countries present power supply problems, and in some cases due to fuel supply shortages. In Indonesia, potential demand seems to be limited to power generation in some of the islands, especially considering existing plans for generation decentralization policies.

When launching a program for flared gas recovery, the preparation work will be important to optimize the chain.

More particularly, the preparation should include the following steps:

- identification of the strategic facilities to assess vent and flare gas,

- definition of the flare/vent gas rates and compositions,

- development of a mitigation plan, covering the selection of the optimum chain or combination of both options,

- preliminary economic evaluations. 